\title{
A Literature Review of the Potential Impact of Medication on Vitamin D Status
}

\section{Michael Wakeman (ID)}

Faculty of Health and Wellbeing, University of Sunderland, Sunderland, SRI 3SD, UK
Correspondence: Michael Wakeman Faculty of Health and Wellbeing, University of Sunderland, Chester Road, Sunderland, SRI 3SD, UK

Tel +44 I335350935

Email mikepwakeman@gmail.com
Abstract: In recent years, there has been a significant increase in media coverage of the putative actions of vitamin $\mathrm{D}$ as well as the possible health benefits that supplementation might deliver. However, the potential effect that medications may have on the vitamin D status is rarely taken into consideration. This literature review was undertaken to assess the degree to which vitamin D status may be affected by medication. Electronic databases were searched to identify literature relating to this subject, and study characteristics and conclusions were scrutinized for evidence of potential associations. The following groups of drugs were identified in one or more studies to affect vitamin D status in some way: anti-epileptics, laxatives, metformin, loop diuretics, angiotensin-converting enzyme inhibitors, thiazide diuretics, statins, calcium channel blockers, antagonists of vitamin $\mathrm{K}$, platelet aggregation inhibitors, digoxin, potassium-sparing diuretics, benzodiazepines, antidepressants, proton pump inhibitors, histamine $\mathrm{H}_{2}$-receptor antagonists, bile acid sequestrants, corticosteroids, antimicrobials, sulphonamides and urea derivatives, lipase inhibitors, hydroxychloroquine, highly active antiretroviral agents, and certain chemotherapeutic agents. Given that the quality of the data is heterogeneous, newer, more robustly designed studies are required to better define likely interactions between vitamin $\mathrm{D}$ and medications. This is especially so for cytochrome P450 3A4 enzyme (CYP3A4)-metabolized medications. Nevertheless, this review suggests that providers of health care ought to be alert to the potential of vitamin $\mathrm{D}$ depletions induced by medications, especially in elderly people exposed to multiple-drug therapy, and to provide supplementation if required.

Keywords: ergocalciferol, cholecalciferol, vitamin D, medication interactions, drug interactions

\section{Introduction}

Classically, the function of fat-soluble vitamin D is considered to be regulating the absorption of calcium and management of its homeostasis, and hence its role in musculoskeletal health is well recognized. However, in recent years evidence has begun to appear that suggests that certain non-skeletal conditions, such as cardiovascular and coronary heart disease, diabetes, some cancers, multiple sclerosis, Parkinson's disease, age-related cognitive decline, and arthritis, may be associated with suboptimal concentrations of 25 -hydroxyvitamin $\mathrm{D}(25(\mathrm{OH}) \mathrm{D})$ in the serum. But it remains unclear whether inadequate vitamin $\mathrm{D}$ could be the result or the cause of these disorders. ${ }^{1}$ Nevertheless, it is commonly understood that the vitamin facilitates absorption of calcium from the gastrointestinal tract, promotes mineralization of osteoid tissue in newly formed bone, and also performs a significant role in the function of muscle. ${ }^{2}$ A chronic deficiency in the vitamin is well 
recognized to be damaging to skeletal health, which can result in osteomalacia in adults or rickets in children. ${ }^{3}$ In these conditions, 25(OH)D serum concentrations are typically $<20 \mathrm{nmol} / \mathrm{L}$. Insufficiency of vitamin $\mathrm{D}-$ a situation where the deficiency is deemed to be less severe - has been shown to result in secondary hyperparathyroidism, along with higher levels of bone loss, and in older people, increased muscle weakness leading to falls and subsequent fragility fractures. ${ }^{2}$

The European Foods Standards Agency (EFSA) has approved health claims for vitamin D relating to

contribution to the normal function of the immune system; contribution to the maintenance of normal bones and teeth; normal growth and development of bone in children; normal absorption/utilisation of calcium and phosphorus; normal blood calcium concentrations and maintenance of normal muscle function. ${ }^{5-7}$

However, despite there being a number of ongoing debates relating to specific requirements for the vitamin, its status, and subsequent effects on health, there is a consensus that the prevention of vitamin D deficiency is an important public health issue, especially since low levels appear to be prevalent in certain demographics, such as the institutionalized elderly, various ethnic groups, pregnant women, and young children. ${ }^{8,9}$

Vitamin D is manufactured as a supplement, as either vitamin $\mathrm{D}_{2}$ (ergocalciferol) or vitamin $\mathrm{D}_{3}$ (cholecalciferol). Cholecalciferol is endogenously formed in the skin following exposure to ultraviolet (UV) radiation. It is also present in liver, fish, and eggs. In the liver, hepatic 25-hydoxylases (including cytochrome P450 (CYP) enzymes 3A4, 2R1, and 27A1) convert both ergocalciferol and cholecalciferol to the main circulating form, 25-hydroxycholecalciferol $\left(25(\mathrm{OH}) \mathrm{D}_{3}\right)$. In turn, the active species, 1,25-dihydroxycholecalciferol $\left(1,25(\mathrm{OH})_{2} \mathrm{D}\right)$, is converted via $1 \alpha$-hydroxylase (CYP27B1) both in the kidney and at a local tissue level. The 24-hydroxylase enzyme (CYP24A1) is responsible for catabolism of vitamin $\mathrm{D}$ metabolites.

1,25-Dihydroxycholecalciferol $\left(1,25(\mathrm{OH})_{2} \mathrm{D}\right)$ affects intracellular signalling, and can induce either rapid or slower genomic responses. In the former case, it can initiate membrane-associated signal transduction, and in the latter, it can affect expression of those genes that contain a response element for vitamin D through initiation or inhibition of transcription. ${ }^{10}$ Studies show that 1,25 $(\mathrm{OH})_{2} \mathrm{D}$ can induce the transcription of specific enzymes involved in both phase $1^{11}$ and phase 2 biotransformations, ${ }^{12}$ and multidrug-resistant protein 1 , p-glycoprotein, ${ }^{13}$ as well as enzymes that control the bioavailability and metabolism of certain drugs.

Because $1,25(\mathrm{OH})_{2} \mathrm{D}$ is more metabolically active, its presence in tissues is tightly regulated, and it is present in only picomolar concentrations in the circulation; hence, in terms of assessing clinical vitamin D status, $25(\mathrm{OH}) \mathrm{D} 3$ is typically used as the chosen appropriate marker. However, the definition of sufficiency is still open to debate. Hence, some institutions propose concentrations of $\geq 20 \mathrm{ng} / \mathrm{mL}$ of $25(\mathrm{OH}) \mathrm{D}$ in the serum as providing sufficiency, based specifically on levels thought to be required for the prevention of osteoporosis, ${ }^{14}$ whereas others suggest a status of $\geq 30-32 \mathrm{ng} / \mathrm{mL}(75-80 \mathrm{nmol} / \mathrm{L})$ to be optimal for populations of healthy individuals. ${ }^{15-17}$ There are also interindividual issues which need to be taken into consideration in the interpretation of serum concentrations. For example, obese individuals are commonly reported to exhibit lower levels of 25(OH)D than subjects of normal weight. This has been suggested to be due to sequestration in adipose tissue, which is known to be a significant site for storage of the vitamin. ${ }^{18}$ During the winter months, UV intensity is not sufficient at latitudes $>40^{\circ} \mathrm{N}$ to effect skin synthesis of cholecalciferol, leading to seasonal variation in vitamin $\mathrm{D}$ status in some individuals ${ }^{19}$ and one study suggests that higher concentrations of $25(\mathrm{OH}) \mathrm{D}$ occur in men, although reasons for this remain unknown. ${ }^{20}$ Other factors impacting on vitamin $\mathrm{D}$ status include supplementation, dark skin, and increasing age. ${ }^{21,22}$

In vitro studies suggest that while around $50 \%$ of all medications are metabolized by the phase I biotransformation enzyme 25-hydroxylase CYP3A4, which also transforms both supplemental forms of vitamin D to $25(\mathrm{OH}) \mathrm{D}$, many other therapeutic entities may also inhibit or induce its activity. ${ }^{22,23}$ Given that CYP3A4 is active in both intestinal mucosal enterocytes and hepatocytes, ${ }^{24,25}$ it is likely that interactions with oral vitamin $\mathrm{D}$ consumption are of greater significance than those of intravenously administered drugs. Because the CYP3A4 gene has an element responsive to vitamin $\mathrm{D}$, the presence of 1,25 $(\mathrm{OH})_{2} \mathrm{D}$ may up-regulate its expression, which, in turn, could affect the metabolism of medications that depend on CYP3A4 for activation. ${ }^{13,26,27}$ Other potential interactions may result in an increased risk of hypercalcaemia when used together with calcium-sparing drugs, and/or limited absorption of vitamin D supplements if consumed alongside medications which either enhance the elimination of dietary fat or inhibit its absorption. 
That suboptimal vitamin D levels are a common issue, even in prosperous countries, is typified by an analysis in the UK that reported the lowest mean concentrations of 25 $(\mathrm{OH}) \mathrm{D}$ between January and March and the highest during July to September. ${ }^{28}$ The study also reveals that $24 \%$ of females aged 11-18, males aged 19-64, and females aged 65 years and over have a year-round concentration below $25 \mathrm{nmol} / \mathrm{L}$ plasma $25(\mathrm{OH}) \mathrm{D}$, which is the World Health Organization (WHO) threshold for vitamin D deficiency, as do $22 \%$ of females aged between 19 and 64 and $17 \%$ of males aged 65 years and over. This increases to around $40 \%$ in males aged 11-64 during January to March, and $29 \%$ of males aged 65 years and over.

This paper aims to summarize the published literature on the potential effects of medication on vitamin D status and to consider the implications that these could have a further impact on populations that are likely to be already deficient or depleted, and where chronic exposure to polypharmacy may further compromise this situation.

\section{Methods}

Studies published in peer-reviewed journals were considered for inclusion in the current review. The methods used and results obtained from the included papers were required to be well described, with appropriate data collection and analysis performed. The following electronic databases - MEDLINE via PubMed, Embase, Scopus, and CINAHL - were searched through to January 2021. Initially, this strategy was employed using keywords and the Medical Subject Headings (MeSH) "ergocalciferol", "cholecalciferol", "vitamin D", "medication interactions", and "drug interactions". As a result of references identified in this primary search, additional terms including "statin", "hydroxymethylglutaryl-CoA reductase inhibitors", "colestyramine", "cimetidine", "antibiotics", "glucocorticoids", "anticonvulsants", "laxatives", "diuretics", "cyclosporins", "thiazides", "HIV protease inhibitors", "histamine H2 antagonists", "antidepressants", "ACE inhibitors", "calcium channel blockers", "polypharmacy", and "immunosuppressive agents" were added and subsequently searched. Study quality and findings were abstracted according to relevance. Additional references and/or review articles revealed as a result of the primary research were also reviewed. In total, 576 titles were identified and 204 reports met the inclusion criteria.
Results

\section{Medications Impacting on Vitamin D Status}

A summary of the findings of key studies are presented in Table 1.

\section{Anti-Epileptic Drugs (AEDs)}

It has been recognized since the 1960 s that there appears to be an association between metabolic bone abnormalities, such as osteomalacia, and the use of antiepileptic drugs (AEDs). Subsequently, a number of prospective and cohort studies have demonstrated an association between their use and reduced bone mineral density (BMD), together with an elevated risk of fracture.

\section{Enzyme-Inducing Anti-Epileptic Drugs (EIAEDs)}

Carbamazepine, phenobarbital, and phenytoin all increase the hepatic catabolism of vitamin D to inactive metabolites, thereby negatively affecting the absorption of calcium. ${ }^{29-31}$ This has been observed to result in hypocalcaemia and osteomalacia, especially as a result of prolonged use, such as in patients taking carbamazepine for 6 months or more, or where other enzyme-inducing anticonvulsants are co-prescribed, or when additional vitamin $\mathrm{D}$ deficiency risk factors occur, and these patients are likely to require calcium and vitamin $\mathrm{D}$ supplements as a result. ${ }^{29,31}$ The daily dose of vitamin $\mathrm{D}$ required to correct these deficits may differ, depending on the individual, from $10 \mu \mathrm{g}$ (400 units) to $100 \mu \mathrm{g}$ (4000 units), which necessitates that in high-risk patients, serum vitamin D and calcium status be monitored on a regular basis. ${ }^{32}$ However, unfortunately, many studies combine data for a variety of patients using either different individual or multiple AEDs, and fail to adjust for either duration of treatment or dose. ${ }^{33-54}$

In the healthy kidney, CYP24A1 activity likely dominates $1,25(\mathrm{OH})_{2} \mathrm{D}$ and $25(\mathrm{OH}) \mathrm{D}$ catabolism, whereas CYP3A4 activity is predominant in this metabolic process in the liver and small intestine. Between $10 \%$ and $30 \%$ of patients using phenobarbitone or phenytoin show radiological or biochemical evidence of decreased vitamin D levels. ${ }^{55}$ Evidence of osteomalacia may occur within several months after initiation of anticonvulsant therapy and it is likely that concurrent use of different anticonvulsants will result in additive effects induced by these enzymes in the liver. Here, the modifying effects of degree of sunlight 
Table I Summary of the Findings of Key Studies

\begin{tabular}{|c|c|c|}
\hline Medication & Outcomes from Key Studies & References \\
\hline \multicolumn{3}{|l|}{ Antidiabetic Medications } \\
\hline Metformin & $\begin{array}{l}\text { Users of oral antidiabetics were observed in a cohort study to have on average lower } \\
\text { mean } 25(\mathrm{OH}) \mathrm{D} \text { serum concentrations of } 7.3 \mathrm{nmol} / \mathrm{L} \text { compared with diabetics not } \\
\text { using these drugs. } \\
\text { In two similarly designed studies, with a total of over II,500 patients, a negative } \\
\text { association between vitamin D status and oral antidiabetic use was observed, and a } \\
\text { further cross-sectional study identified a specific effect due to metformin only. }\end{array}$ & {$[76,78-80]$} \\
\hline Thiazolidinediones (TDZs) & $\begin{array}{l}\text { The decrease in bone mineral density (BMD) and the increase in risk of fracture in } \\
\text { type } 2 \text { diabetes (T2D) have been shown to be exacerbated as a result of prescription } \\
\text { of TZDs to improve insulin sensitivity. } \\
\text { A systematic review and meta-analysis suggests that TZD use may result in bone loss } \\
\text { that may be specific and moderate in women. } \\
\text { Chronic TZD treatment has been reported to elevate the risk of bone fracture more } \\
\text { in those women already at a greater risk for bone loss, osteoporosis, and bone } \\
\text { fracture, than in men. } \\
\text { T2D patients on antidiabetic therapies are likely to have a reduced intake of nutrients } \\
\text { essential for bone health, such as vitamin D, calcium, and magnesium. }\end{array}$ & {$[83-85,88-90]$} \\
\hline \multicolumn{3}{|l|}{ Diuretics } \\
\hline Thiazide Diuretics & $\begin{array}{l}\text { Associations with vitamin D levels appear mixed. } \\
\text { The combination of supplementation with vitamin D (which enhances absorption of } \\
\text { intestinal calcium) and thiazide diuretics (which decrease calcium excretion in the } \\
\text { urine) and may theoretically result in hypercalcaemia, or exacerbate it. None of four } \\
\text { additional studies reported that thiazide treatment resulted in significant alterations } \\
\text { in concentrations of } 25(\mathrm{OH}) \mathrm{D} \text {. }\end{array}$ & [91-96] \\
\hline Loop Diuretics & $\begin{array}{l}\text { The use of loop diuretics resulted in associations with } 25(\mathrm{OH}) \mathrm{D} \text { being either negative } \\
\text { or not present, whilst those with } \mathrm{I}, 25(\mathrm{OH})_{2} \mathrm{D} \text { were similarly mixed. } \\
\text { A randomized clinical trial comparing placebo with loop diuretic use showed } \\
\text { elevation of both } \mathrm{I}, 25(\mathrm{OH})_{2} \mathrm{D} \text { and serum parathyroid hormone }(\mathrm{PTH}) \text { levels, } \\
\text { together with an increased renal calcium excretion that may induce } \\
\text { hyperparathyroidism, which, in turn, increases hydroxylation of } 25(\mathrm{OH}) \mathrm{D} \text {, resulting in } \\
\text { increased concentrations of } \mathrm{I}, 25(\mathrm{OH})_{2} \mathrm{D} \text {. }\end{array}$ & {$[76,91,97]$} \\
\hline Potassium-Sparing Diuretics & $\begin{array}{l}\text { van Ortein-Luiten et al highlighted an inverse association between potassium-sparing } \\
\text { diuretics and vitamin } D \text { in the elderly. } \\
\text { Another cross-sectional study in patients of a similar demographic failed to replicate } \\
\text { these findings. }\end{array}$ & {$[76,80]$} \\
\hline \multicolumn{3}{|l|}{$\begin{array}{l}\text { Medications Used in } \\
\text { Cardiovascular Disease }\end{array}$} \\
\hline Calcium Channel Blockers & $\begin{array}{l}\text { In a cohort study of elderly individuals, the use of calcium channel blockers (such as } \\
\text { verapamil and diltiazem) resulted in a reduction of } 7.7 \mathrm{nmol} / \mathrm{L} \text { in levels of } 25(\mathrm{OH}) \mathrm{D} \text { in } \\
\text { serum in contrast to non-use. } \\
\text { As verapamil and diltiazem are known to inhibit CYP3A4, the anabolism of } 25(\mathrm{OH}) \mathrm{D} \\
\text { precursors in the skin through exposure to UV radiation may be decreased as a } \\
\text { consequence, thus resulting in lower serum } 25(\mathrm{OH}) \mathrm{D} \text {. } \\
\text { Drugs, such as nifedipine, which are ligands for the nuclear pregnane } X \text { receptor } \\
\text { (PXR) can induce an increase in vitamin D catabolism. }\end{array}$ & {$[23,75,76,98-101]$} \\
\hline
\end{tabular}

(Continued) 
Table I (Continued).

\begin{tabular}{|c|c|c|}
\hline Medication & Outcomes from Key Studies & References \\
\hline $\begin{array}{l}\text { Angiotensin-Converting } \\
\text { Enzyme (ACE) Inhibitors }\end{array}$ & $\begin{array}{l}\text { ACE inhibitor use in a cohort of elderly patients resulted in a } 7.6 \mathrm{nmol} / \mathrm{L} \text { reduction in } \\
25(\mathrm{OH}) \mathrm{D} \text { serum levels compared with those not prescribed this type of medication. } \\
\text { German and Dutch cross-sectional studies also reported lower levels of } 25(\mathrm{OH}) \mathrm{D} \text { in } \\
\text { those using these drugs. } \\
\text { A further examination of the cohort in the Dutch study and two quasi-experimental } \\
\text { studies showed no relationship. } \\
\text { Another study identified higher concentrations in those prescribed quinapril, but } \\
\text { reported no change in enalapril users. }\end{array}$ & {$[76,102-106]$} \\
\hline Statins & $\begin{array}{l}\text { Statins exert their cholesterol-lowering effects by inhibiting the } \\
\text { hydroxymethylglutaryl-coenzyme A reductase (HMG CoA reductase) enzyme, which } \\
\text { is rate limiting in cholesterol synthesis; hence, it is thought that statins could also } \\
\text { reduce the synthesis of vitamin D. } \\
\text { Since simvastatin, lovastatin, and atorvastatin are primarily metabolized by CYP3A4, } \\
\text { competition for this enzyme may present another route for drug-vitamin } \\
\text { interactions. } \\
\text { CYP2C9 primarily metabolizes rosuvastatin and fluvastatin, whereas pravastatin and } \\
\text { pitavastatin interact minimally with hepatic enzymes, instead being degraded in the } \\
\text { stomach. } \\
\text { Reports from several groups have indicated that atorvastatin administration may } \\
\text { increase circulating } 25(O H) D \text { concentrations. } \\
\text { Two studies investigating the effects of pravastatin therapy on vitamin D status } \\
\text { identified no significant differences in } 25(O H) D \text { levels. } \\
\text { Rosuvastatin has been demonstrated to robustly increase levels of vitamin D. } \\
\text { In a prospective cohort study in hyperlipidaemic patients, compared with baseline } \\
\text { levels, statistically significant increases were observed in both } 25 \text {-hydroxyvitamin D } \\
\text { and I,25-hydroxyvitamin D. } \\
\text { The same authors later reported that } 25 \text {-hydroxyvitamin D levels increased with } \\
\text { rosuvastatin treatment compared to fluvastatin. } \\
\text { Well-designed larger multicentre trials are required to resolve the issue. }\end{array}$ & $\begin{array}{l}{[105,108-} \\
119,122,123]\end{array}$ \\
\hline Bile Acid Sequestrants & $\begin{array}{l}\text { Bile acid sequestrants may also bind with vitamin } \mathrm{D} \text {, and since its metabolites are also } \\
\text { present in bile, an elevated excretion of bile acids may also reduce levels of this and } \\
\text { other fat-soluble vitamins. } \\
\text { One trial in children with familial hypercholesterolaemia reported a significant } \\
\text { decrease in vitamin } \mathrm{D} \text { status in those taking } 8 \mathrm{~g} \text { colestyramine daily over the period of } \\
\text { a year. } \\
\text { The reduction in absorption of vitamin } \mathrm{D} \text { induced by colestyramine can occasionally } \\
\text { lead to osteomalacia in patients receiving daily doses of colestyramine of }>32 \mathrm{~g} \text { for } \\
\text { prolonged periods of over } 2 \text { years. } \\
\text { Three other studies on the same class of medications reported the opposite findings. }\end{array}$ & {$[116,128-135]$} \\
\hline Vitamin K Antagonists & $\begin{array}{l}\text { Two cross-sectional studies from the Netherlands indicate that patients prescribed } \\
\text { vitamin } \mathrm{K} \text { antagonists experienced more greatly reduced concentrations of } 25(\mathrm{OH}) \mathrm{D} \\
\text { than non-users. } \\
\text { This was confirmed in a cross-sectional study from Germany of } 7553 \text { males. } \\
\text { Four other studies did not report this effect. }\end{array}$ & {$[76,79,80,136-139]$} \\
\hline $\begin{array}{l}\text { Platelet Aggregation } \\
\text { Inhibitors }\end{array}$ & $\begin{array}{l}\text { Two cross-sectional studies failed to report an inverse relationship between the use } \\
\text { of platelet aggregation inhibitors and vitamin D status. } \\
\text { However, three other studies have found to the contrary. }\end{array}$ & {$[76,79,80,|40| 4 \mid]$,} \\
\hline
\end{tabular}

(Continued) 
Table I (Continued).

\begin{tabular}{|c|c|c|}
\hline Medication & Outcomes from Key Studies & References \\
\hline Heparin & $\begin{array}{l}\text { When used for } 3 \text { months or more, at a dose of } \geq 15,000 \mathrm{IU} \text {, unfractionated heparin } \\
\text { has been demonstrated to be associated with osteoporotic fractures and reduced } \\
\text { bone density, and vitamin D metabolism is also negatively affected. } \\
\text { Low molecular weight heparins are unlikely to reduce bone density to the same } \\
\text { extent as unfractionated heparin, but there is the possibility that these compounds } \\
\text { may adversely affect vitamin D metabolism. }\end{array}$ & {$[206-214]$} \\
\hline Digoxin & $\begin{array}{l}\text { In one Dutch cross-sectional study of geriatric patients, a negative, tending towards a } \\
\text { statistically significant inverse relationship between digoxin and vitamin D was } \\
\text { identified. } \\
\text { Statistical significance was not confirmed in other studies. }\end{array}$ & {$[76,79,80]$} \\
\hline \multicolumn{3}{|l|}{ CNS Medications } \\
\hline Benzodiazepines & $\begin{array}{l}\text { A lack of a significant effect of benzodiazepines has been reported in three cross- } \\
\text { sectional studies. } \\
\text { Sohl et al, in a subsequent subgroup analysis of participants in their study, did observe } \\
\text { a significant inverse association between this category of drug and vitamin D. }\end{array}$ & {$[76,80, \mid 42]$} \\
\hline Antidepressants & $\begin{array}{l}\text { The finding of an inverse relationship between the use of selective serotonin reuptake } \\
\text { inhibitors (SSRIs) and } 25(\mathrm{OH}) \mathrm{D} \text { levels was reported in two cross-sectional studies. }\end{array}$ & {$[80,142]$} \\
\hline $\begin{array}{l}\text { Enzyme-Inducing } \\
\text { Antiepileptic Drugs (AEDs) }\end{array}$ & $\begin{array}{l}\text { A systematic review suggests that in adult patients treated with AEDs, vitamin D } \\
\text { deficiency is commonly observed, with consequently reduced levels and frequency of } \\
\text { deficiency differing according to the medication used. }\end{array}$ & [61] \\
\hline Newer Antiepileptic Drugs & $\begin{array}{l}\text { A large retrospective cohort study of over } 15,000 \text { patients reported an elevated risk } \\
\text { of bone fracture for gabapentin but none with lamotrigine, levetiracetam, or } \\
\text { oxcarbazepine. } \\
\text { However, a smaller, similarly retrospective, study of } 560 \text { patients concluded that } \\
\text { there was no association between newer AEDs and lower BMD. } \\
\text { Other studies are conflicting. }\end{array}$ & [63-70] \\
\hline \multicolumn{3}{|l|}{$\begin{array}{l}\text { Gastrointestinal } \\
\text { Medications }\end{array}$} \\
\hline $\begin{array}{l}\text { Proton Pump Inhibitors } \\
\text { (PPIs) }\end{array}$ & $\begin{array}{l}\text { Theoretically, the hypochlorhydria induced by this class of medication could result in } \\
\text { malabsorption of calcium, with the suggestion that prolonged exposure to acid } \\
\text { suppression might be a clinically relevant consequence contributing to increased } \\
\text { osteoporosis risk. } \\
\text { Vitamin D and calcium for the elderly where high-dose PPI therapy, especially over a } \\
\text { long-term period, is being employed, is recommended. }\end{array}$ & [144-146] \\
\hline $\begin{array}{l}\text { Histamine } \mathrm{H}_{2} \text {-Receptor } \\
\text { Antagonists }\end{array}$ & $\begin{array}{l}\text { Preclinical studies demonstrate that cimetidine inhibits } 25 \text {-hydroxylases. } \\
\text { A small study of nine patients with cimetidine-treated gastric ulcers identified no } \\
\text { significant decrease in } 25(\mathrm{OH}) \text { D serum concentrations from baseline while patients } \\
\text { were receiving the medication; however, levels rose significantly once cimetidine was } \\
\text { discontinued. } \\
\text { Preclinical models fail to identify the same interaction with ranitidine. }\end{array}$ & {$[147-150]$} \\
\hline
\end{tabular}

(Continued) 
Table I (Continued).

\begin{tabular}{|c|c|c|}
\hline Medication & Outcomes from Key Studies & References \\
\hline Lipase Inhibitors & $\begin{array}{l}\text { Orlistat binds within the gastrointestinal tract to the active sites of pancreatic and } \\
\text { gastric lipases and thereby blocks absorption of fats in the diet, thus limiting calorie } \\
\text { intake; hence, vitamin D uptake and absorption from the diet and supplements may } \\
\text { be inhibited. } \\
\text { Three studies reported decreased concentrations of } 25(\mathrm{OH}) \mathrm{D} \text { in those receiving } \\
\text { orlistat. However, decreases were similarly reported in the control groups, which } \\
\text { may be attributable to a reduction in total fat intake. }\end{array}$ & [194-198] \\
\hline Laxatives & $\begin{array}{l}\text { A reduction in absorption of vitamin } \mathrm{D} \text { and calcium from food as a result of high } \\
\text { doses and prolonged use of stimulant laxatives can lead to hypocalcaemia and } \\
\text { osteomalacia. }\end{array}$ & [73] \\
\hline \multicolumn{3}{|l|}{$\begin{array}{l}\text { Anti-Inflammatory } \\
\text { Medications }\end{array}$} \\
\hline Corticosteroids & $\begin{array}{l}\text { A commonly observed complication of corticosteroid therapy is osteoporosis, and } \\
\text { the impact of this class of medication on vitamin } D \text { metabolism as a potential } \\
\text { contributory factor has been the subject of a number of studies. } \\
\text { The majority identified no significant differences in levels of } 25(\mathrm{OH}) \mathrm{D} \text { in comparison } \\
\text { to pretreatment or in controls. } \\
\text { Lems et al identified that treatment of healthy controls with low-dose prednisone } \\
\text { reduced } 25(\mathrm{OH}) \mathrm{D} \text { levels. } \\
\text { Lund et al similarly reported } 25(\mathrm{OH}) \mathrm{D} \text { concentrations to be significantly reduced in a } \\
\text { study of patients with rheumatoid arthritis taking low-dose prednisone, but none was } \\
\text { considered to be deficient. } \\
\text { Two other centres reported a lack of significant differences in pre- versus post- } \\
\text { treatment } 25(\mathrm{OH}) \mathrm{D} \text { concentrations with prednisolone. } \\
\text { In the USA, those taking prednisolone } \geq 7.5 \mathrm{mg} / \text { day (or corresponding doses of other } \\
\text { corticosteroids) for } \geq 6 \text { months are advised to take a daily vitamin D supplement of } \\
800 \text { IU and to maintain a calcium intake of } 1500 \text { mg each day. }\end{array}$ & {$[151-163,181]$} \\
\hline $\begin{array}{l}\text { Inhaled Corticosteroids } \\
\text { (ICS) }\end{array}$ & $\begin{array}{l}\text { One study failed to identify any effect of inhaled glucocorticosteroids (ICS) on serum } \\
25(\mathrm{OH}) \mathrm{D} \\
\text { Sohl et al, in a cohort study, reported a significant negative association with lower } 25 \\
(\mathrm{OH}) \mathrm{D} \text { in serum in men treated with this class of medication. } \\
\text { One systematic review concluded that ICS use may affect markers of BMD and bone } \\
\text { metabolism in asthmatic patients and those with COPD, as well as healthy adults. } \\
\text { Another meta-analysis identified a significant relationship between greater doses of } \\
\text { ICS and elevated turnover of bone in mild COPD as well as asthmatic patients, but } \\
\text { this failed to reach significance at lower doses of ICS. } \\
\text { A third meta-analysis reported no difference in BMD between asthma patients } \\
\text { receiving long-term ICS treatment and healthy controls. } \\
\text { A later systematic review and meta-analysis found no significant associations between } \\
\text { BMD and fracture risk in asthmatic children and adults receiving long-term ICS } \\
\text { treatment. } \\
\text { Meta-analyses assessing the association between fracture risk in COPD patients and } \\
\text { long-term ICS use have established a modest but significant, dose-dependent } \\
\text { increase. } \\
\text { In summary, the effect of long-term ICS use may negatively influence bone } \\
\text { metabolism and BMD in certain patients, especially those with COPD. }\end{array}$ & $\begin{array}{l}{[76,170,173-176,178-} \\
180]\end{array}$ \\
\hline
\end{tabular}


Table I (Continued).

\begin{tabular}{|c|c|c|}
\hline Medication & Outcomes from Key Studies & References \\
\hline Bronchodilators & $\begin{array}{l}\text { In one case-control study, a greater risk of femur and hip fractures was reported for } \\
\text { larger doses, but this was attenuated after adjusting for underlying disease and oral } \\
\text { glucocorticoid use. } \\
\text { This finding is supported by a 2-year randomized trial assessing BMD in patients } \\
\text { receiving ICS compared to a non-corticosteroid group taking beta2-agonists. }\end{array}$ & {$[182,183]$} \\
\hline Hydroxychloroquine & $\begin{array}{l}\text { One study assessing the predictors and prevalence of deficiency of vitamin } D \text { found it } \\
\text { to be common in systemic lupus erythematosus patients. Those prescribed } \\
\text { hydroxychloroquine had elevated concentrations of } 25(\mathrm{OH}) \mathrm{D} \text { in comparison with } \\
\text { non-users. }\end{array}$ & [199] \\
\hline \multicolumn{3}{|l|}{ Anti-infectives/Antivirals } \\
\hline Antimicrobials & $\begin{array}{l}\text { Six small studies investigated the possibility of an association between the use of } \\
\text { rifampicin and/or isoniazidand vitamin D status. Of these, four reported a decrease in } \\
25(\mathrm{OH}) \mathrm{D} \text {, one identified no change, and one demonstrated an increase. } \\
\text { Osteomalacia has been reported after therapy prolonged for }>\text { I year, especially when } \\
\text { accompanied by low intake of vitamin D. }\end{array}$ & {$[184,185,189-193]$} \\
\hline $\begin{array}{l}\text { Sulphonamides and Urea } \\
\text { Derivatives }\end{array}$ & $\begin{array}{l}\text { A cross-sectional study of } 892 \text { community-living outpatients in the Netherlands } \\
\text { identified a statistically significant negative effect of these medications on vitamin D } \\
\text { status. }\end{array}$ & {$[80]$} \\
\hline $\begin{array}{l}\text { Highly Active Antiretroviral } \\
\text { Therapy (HAART) }\end{array}$ & $\begin{array}{l}\text { Of three clinical studies, two reported lower concentrations of } 25(\mathrm{OH}) \mathrm{D} \text { in serum in } \\
\text { patients prescribed HAART compared with non-users, but this was only statistically } \\
\text { significant in one study. } \\
\text { Reduction of plasma levels of vitamin D has been reported within } 6 \text { months of } \\
\text { initiation of therapy with favirenz-based antiretroviral therapy, but not after longer } \\
\text { term use. }\end{array}$ & [202-205] \\
\hline \multicolumn{3}{|l|}{$\begin{array}{l}\text { Medications Used in } \\
\text { Malignancy }\end{array}$} \\
\hline Chemotherapeutic Agents & $\begin{array}{l}\text { Many of these medications are metabolized by CYP3A4 and hence may interact with } \\
\text { vitamin D. These include tamoxifen, docetaxel, paclitaxel, ifosfamide, etoposide, } \\
\text { vinblastine, vincristine, cyclophosphamide, imatinib, and irinotecan. The effect of the } \\
\text { use of docetaxel and anthracycline-based adjuvant chemotherapy on vitamin D plasma } \\
\text { levels was investigated in a longitudinal evaluation of breast cancer patients with an } \\
\text { early-stage diagnosis, and it was identified that } 30-50 \% \text { were vitamin D deficient at } \\
\text { the initial diagnosis of their breast cancer. } \\
\text { Two other studies of the same chemotherapy regimens failed to report a significant } \\
\text { change in } 25(\mathrm{OH}) \mathrm{D} \text { concentrations; however, in both, patients received vitamin D } \\
\text { supplements. } \\
\text { Another study in a similar group of patients found that nearly all patients had } \\
\text { insufficiency of vitamin D by the completion of neoadjuvant chemotherapy, } \\
\text { accompanied by associated alterations in the calcium/ RANKL/OPG axis, which } \\
\text { suggests a disruption of regulatory mechanisms at a functional level. } \\
\text { Three other studies assessed vitamin D status during chemotherapy. These studies } \\
\text { examined patients diagnosed with colorectal, breast, uterine, and ovarian cancers } \\
\text { treated with a variety of chemotherapeutic drugs (5-fluorouracil, cisplatin, } \\
\text { capecitabine, epirubicin, oxaliplatin, irinotecan, as well as a number of monoclonal } \\
\text { antibodies) and reported a lack of significant changes in concentrations of } 25(O H) D \\
\text { during treatment. }\end{array}$ & {$[215,216,218-223]$} \\
\hline
\end{tabular}

(Continued) 
Table I (Continued).

\begin{tabular}{|l|l|l|}
\hline Medication & \multicolumn{1}{|c|}{ Outcomes from Key Studies } & References \\
\hline Others & & \\
\hline Sunscreens & $\begin{array}{l}\text { Reduction of synthesis of vitamin D in the skin, and hence plasma levels, can occur as } \\
\text { a result of extensive or frequent use of sunscreens, and there is concern that } \\
\text { excessive use or overuse may result in deficiency. }\end{array}$ & {$[22-228]$} \\
\hline
\end{tabular}

exposure and dietary intake are also important to take into consideration. ${ }^{56}$ Supplementation with vitamin D has been demonstrated to result in improvements in the biochemical and radiological changes reported above. ${ }^{57-59}$

One study reported that irrespective of which antiepileptic medication of this type is prescribed, subjects with concentrations of $25(\mathrm{OH}) \mathrm{D}$ considered to be within a "normal" range went into insufficiency and deficiency states upon initiation of treatment, and that this occurred even at subtherapeutic levels of the drug in serum. ${ }^{60}$ The authors therefore suggested that it is worthwhile to recommend vitamin D and calcium supplementation prior to the commencement of any antiepileptic therapy of this type.

The primary finding in a previous systematic review is that in adult patients treated with these AEDs, vitamin D deficiency is commonly observed, with consequent levels and frequency of deficiency differing according to the medication used. ${ }^{61}$ However, the authors question whether the inherently suboptimal levels of vitamin D commonly observed in these patients might act as a confounder. One randomized trial identified that using higher dose vitamin D supplementation could help to stabilize the total hip and spine BMD compared with a lower dose of vitamin D in patients on these AEDs. ${ }^{62}$

\section{Newer AEDs}

Data are limited on newer AEDs and the specific effects on bone. A large retrospective cohort study of over 15,000 patients reported an elevated risk of bone fracture for gabapentin, but not with lamotrigine, levetiracetam, or oxcarbazepine. ${ }^{63}$ However, a smaller, similarly retrospective, study of 560 patients concluded that there was no association between newer AEDs and lower BMD. ${ }^{64}$ Likewise, other studies are conflicting. ${ }^{65-70}$ However, a preclinical study of levetiracetam suggests although bone density was not impaired, there was a negative effect on bone quality, which indicates that traditionally used measures of BMD may not necessarily identify all changes in bone health. ${ }^{71} \mathrm{Wu}$ et al also demonstrated that patients with osteoporosis were more likely to have epilepsy and to have received EIAED or non-CYP450-inducing antiepileptic drug (NEIAED) treatment. ${ }^{72}$ However, a later retrospective study of BMD and some of the more recently introduced anticonvulsants (topiramate, gabapentin, levetiracetam) failed to identify any detrimental effects. ${ }^{64}$

\section{Laxatives}

Laxatives accelerate the movement of foods and liquids through the digestive tract, and this potentially reduced transit time may induce a negative impact on vitamin absorption, especially those that are fat soluble, such as vitamins $\mathrm{A}, \mathrm{D}, \mathrm{E}$, and $\mathrm{K}$, as well as minerals such as calcium, sodium, magnesium, and potassium. This reduction in absorption of vitamin D and calcium from food as a result of high doses and prolonged use of stimulant laxatives can lead to hypocalcaemia and osteomalacia. ${ }^{73}$

\section{Diabetes Medications}

\section{Metformin}

Deficiency of vitamin D is associated with decreased insulin secretion and increased resistance to insulin. ${ }^{74,75}$ Users of oral antidiabetics were observed in a cohort study to have, on average, lower mean $25(\mathrm{OH}) \mathrm{D}$ serum concentrations of $7.3 \mathrm{nmol} / \mathrm{L}$ compared with diabetics not using these drugs. ${ }^{76}$ One group has suggested an intrinsic limitation of this study to be that any potential effect of metformin on lowering levels of vitamin D may have been confounded as a result of the use of supplements when deficiency was diagnosed. ${ }^{77}$ However, in two other similarly designed studies, with a total of over 11,500 patients, a negative association between vitamin $\mathrm{D}$ status and oral antidiabetic use was observed, and a further cross-sectional study identified a specific effect due to metformin only. ${ }^{78-80}$

\section{Thiazolidinediones}

It is well established that patients with type 2 diabetes (T2D) have a higher incidence of bone fractures in 
comparison to their non-diabetic counterparts, despite there being no significant differences in BMD between the two populations. ${ }^{81,82}$ The decrease in BMD and the increase in risk of fracture in T2D have also been shown to be exacerbated as a result of prescription of thiazolidinediones (TZDs) to improve insulin sensitivity. ${ }^{83-85}$ TZDs appear to affect mesenchymal stem cells, resulting in an increase in adipogenesis and a decrease in osteoblast formation. $^{86,87}$

A systematic review and meta-analysis suggests that TZD use may result in bone loss that may be specific and moderate in women. ${ }^{88}$ Likewise, chronic TZD treatment has been reported to elevate the risk of bone fracture more in those women already at a greater risk for bone loss, osteoporosis, and bone fracture, than men. ${ }^{89}$ This situation is exacerbated by reports that T2D patients on antidiabetic therapies are likely to have a reduced intake of nutrients essential for bone health, such as vitamin D, calcium, and magnesium. $^{90}$

\section{Diuretics}

\section{Thiazide Diuretics}

Associations between vitamin D levels and thiazide diuretics appear mixed. ${ }^{91}$ The combination of supplementation with vitamin D (which enhances the absorption of intestinal calcium) and thiazide diuretics (which decrease calcium excretion in the urine) may theoretically result in hypercalcaemia, or exacerbate it. ${ }^{92}$ This is especially likely in those individuals considered to be at risk in these situations, such as those, typically elderly patients, with hyperparathyroidism or compromised renal function. None of four additional studies reported that thiazide treatment resulted in significant alterations in concentrations of 25 $(\mathrm{OH}) \mathrm{D} .^{93-96}$

\section{Loop Diuretics}

The use of loop diuretics resulted in associations with 25 $(\mathrm{OH}) \mathrm{D}$ being either negative or not present, whilst those with $1,25(\mathrm{OH})_{2} \mathrm{D}$ were similarly mixed. ${ }^{91}$ A randomized clinical trial comparing placebo with loop diuretic use showed elevation of both $1,25(\mathrm{OH})_{2} \mathrm{D}$ and serum parathyroid hormone (PTH) levels, together with an increased renal calcium excretion that might induce hyperparathyroidism, which, in turn, increases hydroxylation of $25(\mathrm{OH})$ $\mathrm{D}$, resulting in increased concentrations of 1,25 $(\mathrm{OH})_{2} \mathrm{D} .^{76,97}$

\section{Potassium-Sparing Diuretics}

van Ortein-Luiten et al highlighted an inverse association between these medications and vitamin D in the elderly, ${ }^{80}$ but another cross-sectional study in patients of a similar demographic failed to replicate these findings. ${ }^{76}$

\section{Medications Used in Cardiovascular Disease \\ Calcium Channel Blockers}

In a cohort study of elderly individuals, the use of calcium channel blockers (such as verapamil and diltiazem) resulted in a reduction of $7.7 \mathrm{nmol} / \mathrm{L}$ in levels of $25(\mathrm{OH})$ $\mathrm{D}$ in serum, in contrast to non-use. ${ }^{98}$ As verapamil and diltiazem are known to inhibit CYP3A4, the anabolism of $25(\mathrm{OH}) \mathrm{D}$ precursors in the skin through exposure to UV radiation may be decreased as a consequence, thus resulting in lower serum $25(\mathrm{OH}) \mathrm{D}^{23,75,99-101}$ It also appears that drugs, such as nifedipine, which are ligands for the nuclear pregnane $\mathrm{X}$ receptor (PXR) can induce an increase in vitamin $\mathrm{D}$ catabolism. ${ }^{76}$

\section{Angiotensin-Converting Enzyme (ACE) Inhibitors}

ACE inhibitor use in a cohort of elderly patients resulted in a $7.6 \mathrm{nmol} / \mathrm{L}$ reduction in $25(\mathrm{OH}) \mathrm{D}$ serum levels compared with those not prescribed this type of medication. ${ }^{76}$ However, the potential of polymorphisms in CYP enzymes metabolizing these drugs has also been suggested as a possible confounder. ${ }^{102}$ German and Dutch cross-sectional studies also reported lower levels of $25(\mathrm{OH}) \mathrm{D}$ in those using these drugs, ${ }^{103,104}$ whereas a further examination of the cohort in a Dutch study ${ }^{76}$ and in two quasi-experimental studies ${ }^{102,105}$ showed no relationship. Although another study identified higher concentrations in those prescribed quinapril, it reported no change in enalapril users. ${ }^{106}$ However, as other authors point out,

it cannot be excluded that an inverse association reflects the inverse relationship between low 25(OH)D level and the indication for prescription: high blood pressure and associated comorbidities of diabetes. ${ }^{107}$

\section{Statins}

Statins exert their cholesterol-lowering effects by inhibiting the hydroxymethylglutaryl-coenzyme A reductase (HMG CoA reductase) enzyme, which is rate-limiting in cholesterol synthesis. ${ }^{108}$ Since cholesterol is a precursor of vitamin $\mathrm{D}$, it is thought that statins could also reduce the synthesis of this vitamin. ${ }^{109,110}$ Because simvastatin, 
lovastatin, and atorvastatin are primarily metabolized by CYP3A4, competition for this enzyme may also present another route for drug-vitamin interactions. ${ }^{111,112}$ In contrast, CYP2C9 primarily metabolizes rosuvastatin and fluvastatin, whereas pravastatin and pitavastatin interact minimally with hepatic enzymes, instead being degraded in the stomach. ${ }^{112,113}$

Despite these potentially detrimental effects on vitamin D status, reports from several groups have indicated that atorvastatin administration may increase circulating 25 (OH)D concentrations. ${ }^{105,114-116}$ In one study, researchers identified that patients consuming a daily supplement containing $800 \mathrm{IU}$ of a vitamin D over 6 weeks had levels of atorvastatin or metabolites that were statistically significantly lower than in subjects who were not receiving supplements $(P<0.05) .{ }^{114}$ Nevertheless, cholesterol scores were reduced in the supplementation group, despite these lower atorvastatin concentrations. Both studies investigating the effects of pravastatin therapy on vitamin D status110,116 identified no significant differences in 25(OH)D levels. Rosuvastatin has been demonstrated to robustly increase levels of vitamin $\mathrm{D}$, leading to the suggestion that the beneficial effects of this medication, as identified in the "Justification for the Use of statins in Prevention: an Intervention Trial Evaluating Rosuvastatin (JUPITER)" study, were partly related to this effect in a population that was vitamin D insufficient. ${ }^{117}$

These observations were supported in a prospective cohort study in hyperlipidaemic patients. Of the 91 patients, $19 \%$ were diabetic and $47 \%$ were diagnosed with systemic hypertension, all of whom were statin treatment naïve and were treated for 8 weeks with rosuvastatin. ${ }^{118}$ Compared with baseline levels, statistically significant increases were observed in both 25 -hydroxyvitamin $\mathrm{D}$ and 1,25-hydroxyvitamin $\mathrm{D}$. In a further trial of hyperlipidaemic patients, the same authors later reported that 25-hydroxyvitamin D levels increased with rosuvastatin treatment compared to fluvastatin. ${ }^{119}$ Their findings generated a great deal of controversy, with a number of authors highlighting potential issues, ${ }^{120,121}$ thereby resulting in a consensus that well-designed larger multicentre trials are required to resolve the issue. ${ }^{122,123}$

It is clear that a complex and poorly elucidated relationship exists between statins and vitamin D. However, it is known that both affect the function and metabolism of skeletal muscle, with myalgia linked specifically with vitamin D deficiency. ${ }^{124}$ Certain authors suggest vitamin $\mathrm{D}$ deficiency is associated with increased intolerance to statins as a result of myopathy. ${ }^{125}$ This is supported by one study of 150 patients with hypercholesterolaemia, which identified that individuals who were intolerant to one statin as a result of myalgia also had low serum vitamin D. ${ }^{126}$ These patients were subsequently supplemented with vitamin $\mathrm{D}$ and then recommenced on statin therapy for 8 months. Subsequently, $87 \%$ were reported to be free of myalgia and able to tolerate reinitiation of the statin.

Seven studies with 2420 patients were the subject of a systematic review and meta-analysis, which indicates that low vitamin D levels are indeed associated with myalgia in those receiving statins. ${ }^{127}$ It is suggested that a reversible relationship between deficiency of vitamin D and patients taking statins who experience skeletal muscle myopathy exists, which may be resolved as a result of correcting any underlying deficiency. Alternatively, in certain patients, statin myopathy or drug-unrelated myalgias may be potentiated by deficiency of vitamin D. However, there is not sufficient evidence to support extensive vitamin D status testing in patients with myalgia thought to be the result of statin treatment. Nevertheless, where a patient is known to be deficient in vitamin $\mathrm{D}$ and where a history of intolerance to a statin has been established, a rechallenge with a statin would appear to be a reasonable strategy once levels of vitamin D are confirmed to be replete.

\section{Bile Acid Sequestrants}

These drugs bind with bile acids in the gastrointestinal tract to prevent cholesterol reabsorption and thereby reduce its circulating levels. However, they may also bind with vitamin $\mathrm{D}$, and since its metabolites are also present in bile, an elevated excretion of bile acids may also reduce levels of this and other fat-soluble vitamins. ${ }^{128-133}$ One trial in children with familial hypercholesterolaemia reported a significant decrease in vitamin D status in those taking $8 \mathrm{~g}$ colestyramine daily over the period of a year. ${ }^{128}$ The reduction in absorption of vitamin $\mathrm{D}$ induced by colestyramine can occasionally lead to osteomalacia in patients receiving daily doses of colestyramine of $>32 \mathrm{~g}$ for prolonged periods of over 2 years. ${ }^{133}$ However, three other studies on the same class of medications reported opposite findings. ${ }^{16,134,135}$

\section{Vitamin K Antagonists}

Two cross-sectional studies from the Netherlands indicate that patients prescribed vitamin $\mathrm{K}$ antagonists experienced greater reductions in concentrations of 25(OH)D than nonusers, ${ }^{76,80}$ an effect confirmed in a cross-sectional study 
from Germany of 7553 males. ${ }^{79}$ However, four other studies did not report this effect. ${ }^{136-139}$

\section{Platelet Aggregation Inhibitors}

Whereas two cross-sectional studies ${ }^{76,80}$ failed to report an inverse relationship between the use of these drugs and vitamin D status, three others have done so. ${ }^{79,140,141}$ However, it is suggested that confounding by indication may be a factor. ${ }^{133}$

\section{Digoxin}

In one Dutch cross-sectional study of geriatric patients, a negative, tending towards a statistically significant inverse relationship between digoxin use and vitamin D. ${ }^{80}$ However, statistical significance was not confirmed in other studies. $^{76,79}$

\section{CNS Medications}

\section{Benzodiazepines}

Whereas a lack of a significant effect of benzodiazepines on vitamin D status has been reported in three cross-sectional studies, ${ }^{76,80,142}$ Sohl et al, in a subsequent subgroup analysis of participants in their study, did observe a significant inverse association. ${ }^{76}$

\section{Antidepressants}

The finding of an inverse relationship between the use of selective serotonin reuptake inhibitors (SSRIs) and 25 $(\mathrm{OH}) \mathrm{D}$ levels was reported in two cross-sectional studies.80,142 This may be the result of a negative impact on synthesis of $25(\mathrm{OH}) \mathrm{D}$, as the antidepressant drugs fluvoxamine and fluoxetine are both reported to inhibit the metabolism of CYP enzymes involved in this process. ${ }^{92}$ However, the authors of the two above cross-sectional studies also acknowledged the association that has been reported to exist between depression and vitamin D levels, ${ }^{80,142}$ and this is confirmed by a prospective cohort study, ${ }^{143}$ which suggests that this indication might be considered as a confounding issue.

\section{Disorders of Gastric Acid and Ulceration Medications \\ Proton Pump Inhibitors (PPIs)}

Theoretically, the hypochlorhydria induced by this class of medication could result in malabsorption of calcium, with the suggestion that prolonged exposure to acid suppression may be a clinically relevant consequence contributing to increased osteoporosis risk. ${ }^{144,145}$ One review suggests that it may be advisable to consider supplementation with vitamin D and calcium for the elderly, where highdose PPI therapy, especially over a long-term period, is being employed. ${ }^{146}$

\section{Histamine $\mathrm{H}_{2}$-Receptor Antagonists $\left(\mathrm{H}_{2} \mathrm{RAs}\right)$}

$\mathrm{H}_{2} \mathrm{RAs}$, such as cimetidine, inhibit the secretion of gastric acid by limiting the ability of gastric parietal cells to produce histamine. Preclinical studies demonstrate that cimetidine also inhibits 25-hydroxylases. ${ }^{147,148} \mathrm{~A}$ small study of nine patients with cimetidine-treated gastric ulcers identified no significant decrease in $25(\mathrm{OH}) \mathrm{D}$ serum concentrations from baseline while patients were receiving the medication; however, levels rose significantly once cimetidine was discontinued. ${ }^{149}$ In contrast, preclinical models failed to identify the same interaction with ranitidine. ${ }^{150}$

\section{Corticosteroids}

A commonly observed complication of corticosteroid therapy is osteoporosis, and the impact of this class of medication on vitamin D metabolism as a potential contributory factor has been the subject of a number of studies. ${ }^{151-161}$ Here, the majority identified no significant differences in levels of 25(OH)D in comparison to those measured pretreatment, or in controls. ${ }^{152-154,157,158,160}$ However, Lems et $\mathrm{al}^{155}$ identified that treatment of healthy controls with low-dose prednisone reduced 25(OH)D levels, but since the study was undertaken in the autumn, the authors attributed this observation to seasonal effects. Lund et al ${ }^{159}$ similarly reported $25(\mathrm{OH}) \mathrm{D}$ concentrations to be significantly reduced in a study of patients with rheumatoid arthritis taking low-dose prednisone, but none was considered to be deficient. Two other centres reported a lack of significant differences in pre- versus post-treatment 25 $(\mathrm{OH}) \mathrm{D}$ concentrations with prednisolone. ${ }^{162,163}$

However, while some investigations reviewing this issue identify precisely the specific glucocorticoid that the patients were prescribed, this is not the case in many of the studies, making the conclusions unclear. ${ }^{164-167}$ In one study where this did occur, in adult rheumatoid arthritis patients on daily doses of between 2.5 and $10 \mathrm{mg}$ of prednisone equivalents over at least three months, it was identified that $25(\mathrm{OH}) \mathrm{D}$ concentrations were significantly reduced in corticosteroid users compared to those of healthy controls. ${ }^{165}$ Likewise, two studies in young adults and children identified that those with the most significantly reduced levels of $25(\mathrm{OH}) \mathrm{D}$ were the ones with the highest cumulative exposure to glucocorticoids. ${ }^{168,169}$ A 
limitation to most of these studies is the lack of reporting of any potential confounders, such as differences in body composition, supplemental or dietary vitamin D intake, and exposure to UV sunlight.

Whereas previous studies had not identified any effect of inhaled glucocorticosteroids (ICS) on serum 25(OH) $\mathrm{D},{ }^{170}$ Sohl et al, in a cohort study, reported a significant negative association with lower $25(\mathrm{OH}) \mathrm{D}$ in serum in men treated with this class of medication. ${ }^{76}$ Inhaled corticosteroids are also commonly used in chronic obstructive pulmonary disease (COPD), where deficiency of vitamin D has a high prevalence and where serum concentrations seem to correlate directly with the severity of the condition. Hence, confounding by this indication may contribute to any observed associations between reduced 25(OH)D serum concentrations and inhaled corticosteroid use in this disease. ${ }^{171,172}$

The effects of long-term ( $>12$ months) inhaled corticosteroid (ICS) use on bone are currently unclear. ${ }^{170}$ One systematic review concluded that ICS use may affect markers of BMD and bone metabolism in asthmatic patients and those with COPD, as well as healthy adults. ${ }^{173}$ This is supported by another meta-analysis, where a significant relationship between greater doses of ICS and elevated turnover of bone in mild COPD, as well as asthmatic patients, was observed. ${ }^{174}$ This failed to reach significance at lower doses of ICS. However, a third meta-analysis reported no difference in BMD between asthma patients receiving long-term ICS treatment and healthy controls. ${ }^{175}$ Furthermore, a later systematic review and meta-analysis found no significant associations between BMD and fracture risk in asthmatic children and adults receiving longterm ICS treatment. ${ }^{176}$

In COPD patients, the high prevalence of factors such as smoking, cachexia, and low-grade systemic inflammation ${ }^{176,177}$ is likely to negatively impact bone formation and would possibly have an effect on BMD. Nevertheless, meta-analyses assessing the association between fracture risk in COPD patients and long-term ICS use have established a modest but significant, dosedependent increase. ${ }^{178,179}$ In summary, long-term ICS use may negatively influence bone metabolism and BMD in certain patients, especially those with COPD ${ }^{180}$

In the USA, those taking prednisolone $\geq 7.5 \mathrm{mg} / \mathrm{day}$ (or corresponding doses of other corticosteroids) for 6 months or more are advised to take a daily vitamin D supplement of $800 \mathrm{IU}$ and to maintain a calcium intake of $1500 \mathrm{mg}$ each day. ${ }^{181}$

\section{Bronchodilators}

There are limited human studies investigating the effects of beta2-agonists on bone health. In one case-control study, a greater risk of femur and hip fractures was reported for larger doses, but this was attenuated after adjusting for underlying disease and oral glucocorticoid use. ${ }^{182}$ This finding is supported by a 2-year randomized trial assessing BMD in patients receiving ICS compared to a non-corticosteroid group taking beta2-agonists. ${ }^{183}$

\section{Antimicrobials}

The relationship between tuberculosis (TB) and vitamin D is complex but well established. Historically, exposure to sunshine and supplementation with vitamin D were the mainstays of treatment, prior to the introduction of effective antibiotic therapy. Vitamin D modulates the activity of macrophages and also increases production of cathelicidin, a protein with antimicrobial activity. Enhanced susceptibility to infection with TB has been reported to be associated with deficiency of vitamin $\mathrm{D}$, as has reactivation of latent infections. As CYP3A4 is inhibited by isoniazid and induced by rifampicin, these drugs may affect vitamin $\mathrm{D}$ status. $^{184-187}$

Six small studies investigated the possibility of an association between the use of rifampicin and/or isoniazid and vitamin D status. ${ }^{184,188-192}$ Of these, four reported a decrease in $25(\mathrm{OH}) \mathrm{D},{ }^{184,191,192}$ one identified no change, and one demonstrated an increase. Two of these studies reported that the patients had below-normal pretreatment concentrations of $25(\mathrm{OH}) \mathrm{D},{ }^{184,191}$ but confounders such as season of vitamin D status assessment, supplemental or dietary intake of vitamin $\mathrm{D}$, and stratification by skin tone/ race, or UV exposure were poorly reported. Osteomalacia has been reported after prolonged therapy for more than one year, especially when accompanied by low intake of vitamin D. ${ }^{185,193}$

\section{Sulphonamides and Urea Derivatives}

A cross-sectional study of 892 community-living outpatients in the Netherlands identified a statistically significant negative effect of these medications on vitamin D status. ${ }^{80}$

\section{Lipase Inhibitors}

The weight-loss medication orlistat binds within the gastrointestinal tract to the active sites of pancreatic and gastric lipases and thereby blocks the absorption of fats in the diet, thus limiting calorie intake. ${ }^{194}$ Because it is fat soluble, vitamin D uptake and absorption from the diet and supplements may be inhibited by orlistat. ${ }^{195}$ Three studies 
reported decreased concentrations of $25(\mathrm{OH}) \mathrm{D}$ in those receiving orlistat. ${ }^{196-198}$ However, decreases were similarly reported in the control groups, which may be the result of a reduced total intake of dietary fat.

\section{Hydroxychloroquine}

Because patients with autoimmune conditions often experience photosensitivity, they commonly avoid exposure to sunshine, leading to a concern that a deficiency of vitamin D might be prevalent in this cohort. One study with a comparison group assessed the predictors and prevalence of deficiency of vitamin D in 92 adults with systemic lupus erythematosus (SLE). ${ }^{199}$ Deficiency was found to be common in this cohort, being present in around $75 \%$ of patients, and those prescribed hydroxychloroquine had elevated concentrations of $25(\mathrm{OH}) \mathrm{D}$ in comparison with non-users. The authors suggest that this may be a result of a limited conversion rate of $25(\mathrm{OH}) \mathrm{D}$ to $1,25(\mathrm{OH})_{2} \mathrm{D}$.

\section{Highly Active Antiretroviral Agents}

Highly active antiretroviral therapy (HAART) consists of several classes of antiretroviral medications that variously act by inhibiting different stages of the life cycle of the human immunodeficiency virus (HIV). They include protease inhibitors (PIs), nucleotide reverse transcriptase inhibitors (NtRTIs), nucleoside reverse transcriptase inhibitors (NRTIs), non-nucleoside reverse transcriptase inhibitors (NNRTIs), and entry inhibitors. ${ }^{200}$ Reports indicate that these medications are metabolized by CYP3A4, either inducing or inhibiting its activity, ${ }^{92}$ and hence these effects could affect the rate of synthesis and degradation of 25 (OH)D. This observation was confirmed by Cozzolino et al and others. ${ }^{201-203}$ Of four clinical studies, ${ }^{202-205}$ two reported lower concentrations of $25(\mathrm{OH}) \mathrm{D}$ in serum in patients prescribed HAART compared with non-users,202,204 but this was only statistically significant in one study. ${ }^{202}$ A reduction in plasma levels of vitamin D has been reported within 6 months of initiation of therapy with efavirenz-based antiretroviral therapy, but not after longer term use. ${ }^{205}$

\section{Heparin}

When used for 3 months or more at a dose of $\geq 15,000 \mathrm{IU}$, unfractionated heparin has been demonstrated to be associated with osteoporotic fractures and reduced bone density. ${ }^{206-209}$ This is mainly the result of the direct effects of heparin reducing bone formation and increasing resorption, but vitamin $\mathrm{D}$ metabolism is also negatively affected, ${ }^{206,210,211}$ suggesting that patients on long-term therapy should consider supplements containing calcium and vitamin D. Although low molecular weight heparins are unlikely to reduce bone density to the same extent as unfractionated heparin, there is the possibility that these compounds may adversely affect vitamin D metabolism.$212-214$

\section{Chemotherapeutic Agents}

Many of these medications are metabolized by CYP3A4 and hence may interact with vitamin D. These include tamoxifen, docetaxel, paclitaxel, ifosfamide etoposide, vinblastine, vincristine, cyclophosphamide, imatinib, and irinotecan. $^{215}$

The effect of the use of docetaxel and anthracyclinebased adjuvant chemotherapy on vitamin D plasma levels was investigated in a longitudinal evaluation of breast cancer patients with an early-stage diagnosis. It was identified that $30-50 \%$ were vitamin $\mathrm{D}$ deficient at the initial diagnosis of their breast cancer. ${ }^{216}$ Furthermore, a prospective cohort study identified an inverse association between breast cancer prognosis and serum levels of $25(\mathrm{OH}) \mathrm{D} .^{217}$ However, since lower circulating levels of $25(\mathrm{OH}) \mathrm{D}$ can be attributed to increased storage in adipose tissue, it may be that the apparent reduction in plasma vitamin D levels is associated with increases in body mass index, which often occur in early-stage breast cancer patients receiving adjuvant chemotherapy. ${ }^{18}$ Two other studies of the same chemotherapy regimens failed to report a significant change in $25(\mathrm{OH}) \mathrm{D}$ concentrations; however, in both, patients received vitamin D supplements. ${ }^{218,219}$ Another study in a similar group of patients found that nearly all had insufficiency of vitamin D by the completion of neoadjuvant chemotherapy, accompanied by associated alterations in the calcium/RANKL/OPG axis, which suggests a disruption of regulatory mechanisms at a functional level. $^{220}$

Given that as they age, female breast cancer patients and survivors, in particular, experience elevated rates of bone loss, with a $15 \%$ increased fracture risk compared to their healthy counterparts, the preservation of bone health in breast cancer survivors is a key issue. Here, in a large cohort study of patients with early-stage breast cancer, univariate analyses identified that reduced levels of vitamin D were significantly associated with elevated risks of both recurrence and death. Together, these findings suggest that supplementation with vitamin D appears advisable 
both during chemotherapy and when treatment has been completed, unless specifically contraindicated. ${ }^{218}$

Three other studies ${ }^{221-223}$ assessed the vitamin D status during chemotherapy. These studies examined patients diagnosed with colorectal, breast, uterine, and ovarian cancers, treated with a variety of chemotherapeutic drugs (5-fluorouracil, cisplatin, capecitabine, epirubicin, oxaliplatin, irinotecan, as well as a number of monoclonal antibodies) and reported a lack of significant changes in concentrations of $25(\mathrm{OH}) \mathrm{D}$ during treatment. However, baseline vitamin D deficiency was common, especially in colorectal cancer patients, and more particularly in rectal cancer patients.

\section{Sunscreens}

Reduction of synthesis of vitamin D in the skin, and hence plasma levels, can occur as a result of the extensive or frequent use of sunscreens, ${ }^{224-226}$ and there is concern that excessive use or overuse may result in deficiency. ${ }^{227,228}$

\section{Discussion}

\section{Interpretation of the Data}

Most of the early research in this area consisted of case studies of adverse outcomes or investigated medications commonly associated with osteoporosis, as this evidence suggested that this may be the result of imbalances in the metabolism of vitamin D. However, more recent advances in the understanding of drug metabolism mediated by CYP3A4, and awareness of the role of vitamin D in gene expression of this enzyme, and of drugs metabolized by CYP2R1, CYP24, CYP27A, and CYP27B, have led to a more structured and systematic approach. Nevertheless, this review indicates that increased research is needed to better identify the impact of medications that affect the activity of CYP enzymes involved in the metabolism and regulation of vitamin D. For example, in vitro studies which demonstrate that classes of medications, such as the proton pump inhibitor omeprazole and the antimicrobial agent ketoconazole, which inhibit both CYP3A4 $4^{229,230}$ and CYP24, ${ }^{231}$ require evaluation in a clinical setting to establish their effect, if any, on vitamin D status in humans.

As discussed above, there are limitations in a number of the cited studies. Many are either individual case studies or observational in nature, involving small numbers of patients, or analyses of data collected for reasons other than originally intended, and some were hospital based, without a relevant comparison group. Evaluation of supplemental or additional dietary vitamin D intakes and sun exposure was limited in many, and the lack of consideration of potential confounders, such as body composition and weight, as contributory to either vitamin D status or medication concentrations and drug response, makes it difficult to assess whether the reported impact on levels of vitamin D is the result of a lack of vitamin intake or actually caused by the medication in its own right.

Although not strictly within the remit of this review, the reported effect of smoking on vitamin D status also needs to be considered as an additional possible confounder. Two studies found that smokers had concentrations of serum $25(\mathrm{OH}) \mathrm{D}$ which were reduced compared to nonsmokers. ${ }^{232,233}$ Moreover, a large population study identified odds ratios of severe deficiency of vitamin D $(25(\mathrm{OH})$ $\mathrm{D}<10 \mathrm{ng} / \mathrm{mL}$ ) associated with daily smoking to be 1.47 , and 1.36 for vitamin D deficiency $(25(\mathrm{OH}) \mathrm{D}<20 \mathrm{ng} /$ $\mathrm{mL}){ }^{234}$ In contrast, other studies in men found that smoking was not correlated with levels of $25(\mathrm{OH}) \mathrm{D} .^{235-237}$ However, it may be that these inconsistencies are attributable to differences in the way in which smoking was characterized, and/or smoking intensity, as well as due to inconsistencies in the methodologies used to measure 25 $(\mathrm{OH}) \mathrm{D}$ in serum. For example, one of the latter studies used electrochemiluminescence, which, it is suggested, delivers falsely high levels of $25(\mathrm{OH}) \mathrm{D}$ compared to liquid chromatography-tandem mass spectrometry. ${ }^{238}$

This highlights a very important issue, since determinations of serum vitamin D from a technological perspective are challenging because it is highly hydrophobic and has a number of metabolites. Because methodologies for assessing vitamin D statushave improved significantly in recent years, it is possible that some of the data appearing in a number of the older studies reviewed above may be less accurate or difficult to interpret alongside more recent data. Clearly, in the future, larger and more robustly designed studies addressing this limitation are required to provide clarification about potential interactions between medications and vitamin D. These studies should also use assay methodologies that are standardized to current best practice and carried out in centres which participate in externally validated assessments of the technology specific to vitamin $\mathrm{D}$.

\section{COVID-19 and Vitamin D}

Recently, there has been a significant number of studies from around the world examining the possible association 
between vitamin D status and susceptibility to coronavirus disease 2019 (COVID-19) and its consequences. Many are retrospective cohort analyses, and some are prospective studies involving sufficiently different patient populations, with different degrees of severity of symptoms and prognoses, and indeed varying definitions of the state of vitamin D sufficiency, to make meaningful systematic reviews and/or meta-analyses a difficult process. However, at least six systematic review and meta-analysis studies and two systematic reviews from around the world have appeared within the past 6 months, with a general consensus that it does appear that a higher vitamin D status is generally associated with a lower susceptibility to COVID-19, and better morbidity and mortality outcomes. ${ }^{239-246}$ Nonetheless, the definitive degree of correlation, if any, remains to be established, as does the likely efficacy of vitamin D supplementation as an intervention. However, it is important to recognize that patients experiencing the worst outcomes from the COVID-19 virus tend to be overweight, and experiencing comorbidities such as diabetes and hypertension. ${ }^{247}$ Given that these conditions are typically treated with many of the medications discussed above, often using them concurrently, their potential impact on vitamin D status is likely to be additive. Indeed, many of these medications can also compromise other vitamins and minerals recognized to maintain and support a healthy immune system, which is clearly of benefit in the current pandemic, ${ }^{248}$ but this consequence does not appear to have been taken into consideration in any supplementation guidelines issued to overcome potential suboptimal levels or deficiencies in these patients.

\section{Vitamin D Status and Supplementation}

While experts and consumers strive to establish the validity of the conflicting reviews on vitamin D and COVID19 , it is important not to forget that still today, even in prosperous countries such as the UK, almost one in five adults aged 19-65 years is reported to have a low concentration of serum vitamin $\mathrm{D}(<25 \mathrm{nmol} / \mathrm{L}$, which is considered sufficiency by the UK Scientific Advisory Committee for Nutrition [SACN] in the National Diet and Nutrition Survey [NDNS] $)^{249}$ This places them at a higher risk of the outcomes of a deficiency of vitamin D and conditions such as osteomalacia, rickets, falls, and possibly reduced muscle function and strength in those over 50 years of age.

It is also worth remembering the seasonality of this issue, as SACN reports that on average, ${ }^{250,251}$ around $30-40 \%$ of individuals have vitamin D levels below 25 $\mathrm{nmol} / \mathrm{L}$ in winter and $2-13 \%$ below this level in summer. Moreover, even in summer, a significant proportion of certain cohorts failed to achieve a concentration $\geq 25$ $\mathrm{nmol} / \mathrm{L}$ in plasma $(16 \%$ adults in London, $17 \%$ adults in Scotland, 53\% of females living in the south of England of South Asian origin, and $29 \%$ of pregnant women in London).

This demonstrates the real need to establish the optimal level of vitamin D supplementation in specific groups, as typified by the vulnerable elderly, who may require a more personalized dosage regimen, over and above the universally recommended dose of $10 \mu \mathrm{g}$ in the UK, as a result of the effects of medication on the status of the vitamin, or who are not free-living individuals. For example, in this population, one UK trial assessed the effects of daily vitamin D supplementation compared to placebo over one year using serum measures of vitamin $D$ to assess status. ${ }^{252}$ This randomized placebo-controlled trial was conducted in 305 community-dwelling subjects, 65 years of age or older. The results highlighted that $4000 \mathrm{IU}$ (100 $\mu \mathrm{g})$ vitamin $\mathrm{D}_{3}$ taken on a daily basis is necessary to achieve serum concentrations associated with the lowest risks of disease. However, despite this situation, SACN has set the lowest level for establishing sufficiency (10 ng/ $\mathrm{mL}$ or $25 \mathrm{nmol} / \mathrm{L}$ ) of any scientific society or national advisory body, and as a result recommends a daily supplementation dose of $10 \mu \mathrm{g}$ (400 IU). Here, a paper published by UK researchers in 2021 highlighted that a search for published evidence to support this recommendation was completely unsuccessful. ${ }^{253}$ They argue that

there is considerable evidence to support the higher level for sufficiency ( $20 \mathrm{ng} / \mathrm{mL}$ or $50 \mathrm{nmol} / \mathrm{L}$ ) recommended by the European Food Safety Authority and the American Institute of Medicine and hence greater supplementation (20 micrograms or 800 IU per day)

As already highlighted, given that in the UK serum levels of $25(\mathrm{OH}) \mathrm{D}$ typically diminish by around $50 \%$ during winter, these authors believe "that governments should urgently recommend supplementation with 20-25 micrograms (800-1,000 IU) per day".

Although these higher recommendations, if adopted, should help to meet people's needs on a population basis, there are arguments to suggest that without them, and even possibly with them, supplementation needs to be considered on a more personalized basis in order to achieve optimal status for certain individuals. Carlberg and Haq identified significant interindividual responses to 
supplementation, which suggest that higher than currently recommended reference intakes may be needed, but which can only be identified as a result of monitoring status, which many observers consider unnecessary from a cost perspective. ${ }^{254}$ Without this, it is unlikely that these individuals will benefit as they might from the correct dose of vitamin D supplementation, thereby raising the question of the cost/benefit validity of vitamin status evaluations.

\section{Polypharmacy and Vitamin D}

Finally, in this context, it is highly relevant to note that the incidence of patients taking five or more prescription medications and/or over-the-counter products has risen significantly in recent years. For example, in the UK in the past two decades, the percentage of elderly people aged 65 and over taking five or more items increased four-fold, from $12 \%$ to $49 \%$, while those not taking any medication decreased in the same period, to around one in 13 from one in five ${ }^{255}$. This pattern also appears to be reflected in similar populations in the USA and Europe. ${ }^{256-259}$ Given that many of the medications listed above are extensively used, particularly in the elderly (where a high incidence of low vitamin D status seems to be prevalent), any likely incremental negative outcomes of polypharmacy on levels of vitamin D in this age group are of notable relevance and require special attention from health professionals. This view is supported by two studies performed in the elderly and examining precisely this issue, and cited in this current review. ${ }^{76,80}$ The latter, entitled "Vitamin D deficiency as adverse drug reaction", identified an overall prevalence of polypharmacy (five or more medications used concomitantly) of $65 \%$ and a level of severe polypharmacy (10 or more medications) of $22 \%$ in a population of almost 1000 community-dwelling Dutch citizens. It identified a $49 \%$ level of vitamin D deficiency ( $<50 \mathrm{nmol} / \mathrm{L})$, or $77 \%(<75 \mathrm{nmol} / \mathrm{L})$ depending on the cutoff value used to determine insufficiency. If patients were using a vitamin D supplement, these figures fell to $17 \%$ and $49 \%$, respectively. However, in non-users of vitamin D supplements, after adjustment for age and gender, the other main factor identified as being negatively associated with levels of the vitamin was the use of multiple medications. This was especially highly significant in male patients who had been prescribed severe polypharmacy. ${ }^{80}$ A similar conclusion was reached in the study by Sohl et al, who examined these effects in two different cohorts of over 2000 elderly Dutch patients. ${ }^{76}$ Again, the study data showed that patients prescribed more than one medication had lower concentrations of $25(\mathrm{OH}) \mathrm{D}$ in serum than non-users, leading the authors to recommend that vitamin D supplementation ought to be considered in patients prescribed long-term medication regimens.

\section{Conclusion}

This review has highlighted both significant classes of medications that have the potential to impact on vitamin D status and the need for further research into this important subject. However, until these data are available, all health-care professionals need to be cognizant of the potential for medication-induced effects on vitamin D status. Where appropriate, concentrations of $25(\mathrm{OH}) \mathrm{D}$ in serum should be monitored and, when necessary, vitamin $\mathrm{D}$ dietary supplements recommended, with the objective of achieving adequate levels of vitamin D while also optimizing the efficacy of treatment and limiting drug side-effects and toxicity.

\section{Disclosure}

The author reports no conflicts of interest in this work.

\section{References}

1. Autier P, Boniol M, Pizot C, Mullie P. Vitamin D status and ill health: a systematic review. Lancet Diabetes Endocrinol. 2014;2(1):76-89. doi:10.1016/S2213-8587(13)70165-7

2. Francis R, Aspray T, Fraser W, et al. Vitamin D and bone health: a practical clinical guideline for patient management. Nat Osteoporos Soc. $2013 ; 28$.

3. Thacher TD, Clarke BL. Vitamin D insufficiency. Mayo Clin Proc. 2011;86(1):50-60. doi:10.4065/mcp.2010.0567

4. Department of Health. Nutrition and Bone Health: With Particular Reference to Calcium and Vitamin D. London: The Stationery Office; 1998:49.

5. EFSA Panel on Dietetic Products, Nutrition and Allergies (NDA). Scientific Opinion on the substantiation of health claims related to vitamin D and maintenance of bone and teeth (ID 150, 151, 158), absorption and utilisation of calcium and phosphorus and maintenance of normal blood calcium concentrations (ID 152, 157), cell division (ID 153), and thyroid function (ID 156) pursuant to Article 13 (1) of Regulation (EC) No 1924/2006. EFSA J. 2009;7(10):1227.

6. EFSA Panel on Dietetic Products, Nutrition and Allergies (NDA). Scientific Opinion on the substantiation of health claims related to vitamin $\mathrm{D}$ and normal function of the immune system and inflammatory response (ID 154, 159), maintenance of normal muscle function (ID 155) and maintenance of normal cardiovascular function (ID 159) pursuant to Article 13 (1) of Regulation (EC) No 1924/2006. EFSA J. 2010;8(2):1468.

7. EFSA Panel on Dietetic Products, Nutrition and Allergies (NDA). Scientific Opinion on the substantiation of a health claim related to vitamin $\mathrm{D}$ and contribution to normal bone and tooth development pursuant to Article 14 of Regulation (EC) No 1924/2006. EFSA J. 2014;12(2):3579.

8. Mithal A, Wahl DA, Bonjour JP, et al. Global vitamin D status and determinants of hypovitaminosis D. Osteoporos Int. 2009;20 (11):1807-1820. doi:10.1007/s00198-009-0954-6 
9. Lanham-New SA, Buttriss JL, Miles LM, et al. Proceedings of the rank forum on vitamin D. Br J Nutr. 2011;105(1):144-156. doi:10.1017/S0007114510002576

10. Norman AW, Mizwicki MT, Norman DP. Steroid-hormone rapid actions, membrane receptors and a conformational ensemble model. Nat Rev Drug Discov. 2004;3(1):27-41. doi:10.1038/nrd1283

11. Pascussi JM, Gerbal-Chaloin S, Drocourt L, Maurel P, Vilarem MJ. The expression of CYP2B6, CYP2C9 and CYP3A4 genes: a tangle of networks of nuclear and steroid receptors. Biochim Biophys Acta. 2003;1619(3):243-253. doi:10.1016/S0304-4165 (02)00483-X

12. Chatterjee B, Echchgadda I, Song CS. Vitamin D receptor regulation of the steroid/bile acid sulfotransferase SULT2A1. Methods Enzymol. 2005;400:165-191.

13. Fan J, Liu S, Du Y, Morrison J, Shipman R, Pang KS. Upregulation of transporters and enzymes by the vitamin $\mathrm{D}$ receptor ligands, 1alpha,25-dihydroxyvitamin D3 and vitamin D analogs, in the Caco-2 cell monolayer. J Pharmacol Exp Ther. 2009;330 (2):389-402. doi:10.1124/jpet.108.149815

14. Institute of Medicine. Dietary Reference Intakes for Vitamin D and Calcium. Vol. 2010. Washington, DC: Institute of Medicine; 2011.

15. Bischoff-Ferrari HA, Giovannucci E, Willett WC, Dietrich T, Dawson-Hughes B. Estimation of optimal serum concentrations of 25-hydroxyvitamin D for multiple health outcomes. Am J Clin Nutr. 2006;84(1):18-28. doi:10.1093/ajcn/84.1.18

16. Vieth R, Bischoff-Ferrari H, Boucher BJ, et al. The urgent need to recommend an intake of vitamin $\mathrm{D}$ that is effective. Am J Clin Nutr. 2007;85(3):649-650. doi:10.1093/ajen/85.3.649

17. Hollis BW. Circulating 25-hydroxyvitamin D levels indicative of vitamin D sufficiency: implications for establishing a new effective dietary intake recommendation for vitamin D. J Nutr. 2005;135(2):317-322. doi:10.1093/jn/135.2.317

18. Wortsman J, Matsuoka LY, Chen TC, Lu Z, Holick MF. Decreased bioavailability of vitamin D in obesity. Am J Clin Nutr. 2000;72(3):690-693.

19. Webb AR, Kline L, Holick MF. Influence of season and latitude on the cutaneous synthesis of vitamin D3: exposure to winter sunlight in Boston and Edmonton will not promote vitamin D3 synthesis in human skin. J Clin Endocrinol Metab. 1988;67 (2):373-378. doi:10.1210/jcem-67-2-373

20. Dawson-Hughes B, Harris SS, Dallal GE. Plasma calcidiol, season, and serum parathyroid hormone concentrations in healthy elderly men and women. Am J Clin Nutr. 1997;65(1):67-71. doi:10.1093/ajen/65.1.67

21. Dawson-Hughes B, Heaney RP, Holick MF, Lips P, Meunier PJ, Vieth R. Estimates of optimal vitamin D status. Osteoporos Int. 2005;16(7):713-716. doi:10.1007/s00198-005-1867-7

22. Luo G, Guenthner T, Gan LS, Humphreys WG. CYP3A4 induction by xenobiotics: biochemistry, experimental methods and impact on drug discovery and development. Curr Drug Metab. 2004;5(6):483-505. doi:10.2174/1389200043335397

23. Zhou SF. Drugs behave as substrates, inhibitors and inducers of human cytochrome P450 3A4. Curr Drug Metab. 2008;9(4):310322. doi:10.2174/138920008784220664

24. Watkins PB, Wrighton SA, Schuetz EG, Molowa DT, Guzelian PS. Identification of glucocorticoid-inducible cytochromes P-450 in the intestinal mucosa of rats and man. J Clin Invest. 1987;80 (4):1029-1036. doi:10.1172/JCI113156

25. Kolars JC, Schmiedlin-Ren P, Schuetz JD, Fang C, Watkins PB. Identification of rifampin-inducible P450IIIA4 (CYP3A4) in human small bowel enterocytes. J Clin Invest. 1992;90(5):18711878. doi:10.1172/JCI116064

26. Thummel KE, Brimer C, Yasuda K, et al. Transcriptional control of intestinal cytochrome P-4503A by 1alpha,25-dihydroxy vitamin D3. Mol Pharmacol. 2001;60(6):1399-1406. doi:10.1124/ mol.60.6.1399
27. Lindh JD, Andersson ML, Eliasson E, Bjorkhem-Bergman L. Seasonal variation in blood drug concentrations and a potential relationship to vitamin D. Drug Metab Dispos. 2011;39(5):933937. doi:10.1124/dmd.111.038125

28. Bates B, Lennox A, Prentice A, et al. National diet and nutrition survey results from years 1, 2, 3 and 4 (combined) of the rolling programme (2008/2009-2011/2012). London: Public Health England, Food Standards Agency; 2014.

29. Morijiri Y, Sato T. Factors causing rickets in institutionalised handicapped children on anticonvulsant therapy. Arch Dis Child. 1981;56(6):446-449. doi:10.1136/adc.56.6.446

30. Krause KH, Berlit P, Bonjour JP, Schmidt-Gayk H, Schellenberg B, Gillen J. Vitamin status in patients on chronic anticonvulsant therapy. Int J Vitam Nutr Res. 1982;52(4):375-385.

31. Gough H, Goggin T, Bissessar A, Baker M, Crowley M, Callaghan N. A comparative study of the relative influence of different anticonvulsant drugs, UV exposure and diet on vitamin $\mathrm{D}$ and calcium metabolism in outpatients with epilepsy. $Q \mathrm{~J} \mathrm{Med}$. 1986;59(230):569-577.

32. Hahn TJ, Hendin BA, Scharp CR, Haddad JG. Effect of chronic anticonvulsant therapy on serum 25-hydroxycalciferol levels in adults. $N$ Engl J Med. 1972;287(18):900-904. doi:10.1056/ NEJM197211022871803

33. Bouillon R, Reynaert J, Claes JH, Lissens W, De Moor P. The effect of anticonvulsant therapy on serum levels of 25-hydroxyvitamin D, calcium, and parathyroid hormone. J Clin Endocrinol Metab. 1975;41(6):1130-1135. doi:10.1210/jcem-41-6-1130

34. Jubiz W, Haussler MR, McCain TA, Tolman KG. Plasma 1,25-dihydroxyvitamin D levels in patients receiving anticonvulsant drugs. $J$ Clin Endocrinol Metab. 1977;44(4):617-621. doi:10.1210/jcem-44-4617

35. Pylypchuk G, Oreopoulos DG, Wilson DR, et al. Calcium metabolism in adult outpatients with epilepsy receiving long-term anticonvulsant therapy. Can Med Assoc J. 1978;118(6):635-638.

36. Weisman Y, Andriola M, Reiter E, Gruskin A, Root A. Serum concentrations of 25-hydroxyvitamin D in Florida children: effect of anticonvulsant drugs. South Med J. 1979;72(4):400-401, 408. doi:10.1097/00007611-197904000-00009

37. Christensen CK, Lund B, Lund BJ, Sorensen OH, Nielsen HE, Mosekilde L. Reduced 2,25-dihydroxyvitamin D and 24,25-dihydroxyvitamin D in epileptic patients receiving chronic combined anticonvulsant therapy. Metab Bone Dis Relat Res. 1981;3(1):1722. doi:10.1016/S0221-8747(81)80018-5

38. Hoikka V, Savolainen K, Alhava EM, Sivenius J, Karjalainen P, Repo A. Osteomalacia in institutionalized epileptic patients on long-term anticonvulsant therapy. Acta Neurol Scand. 1981;64 (2):122-131. doi:10.1111/j.1600-0404.1981.tb04394.x

39. Keck E, Gollnick B, Reinhardt D, Karch D, Peerenboom H, Kruskemper HL. Calcium metabolism and vitamin D metabolite levels in children receiving anticonvulsant drugs. Eur J Pediatr. 1982;139(1):52-55. doi:10.1007/BF00442080

40. Lamberg-Allardt C, Wilska M, Saraste KL, Gronlund T. Vitamin D status of ambulatory and nonambulatory mentally retarded children with and without carbamazepine treatment. Ann Nutr Metab. 1990;34(4):216-220. doi:10.1159/000177590

41. Valimaki MJ, Tiihonen M, Laitinen K, et al. Bone mineral density measured by dual-energy x-ray absorptiometry and novel markers of bone formation and resorption in patients on antiepileptic drugs. $J$ Bone Miner Res. 1994;9(5):631-637. doi:10.1002/jbmr.5650090507

42. Telci A, Cakatay U, Kurt BB, et al. Changes in bone turnover and deoxypyridinoline levels in epileptic patients. Clin Chem Lab Med. 2000;38(1):47-50. doi:10.1515/CCLM.2000.008

43. Stamp TC, Round JM, Rowe DJ, Haddad JG. Plasma levels and therapeutic effect of 25-hydroxycholecalciferol in epileptic patients taking anticonvulsant drugs. Br Med J. 1972;4(5831):912. doi:10.1136/bmj.4.5831.9 
44. Tjellesen L, Christiansen C. Serum vitamin D metabolites in epileptic patients treated with 2 different anti-convulsants. Acta Neurol Scand. 1982;66(3):335-341. doi:10.1111/j.16000404.1982.tb06853.x

45. Davie MW, Emberson CE, Lawson DE, et al. Low plasma 25-hydroxyvitamin D and serum calcium levels in institutionalized epileptic subjects: associated risk factors, consequences and response to treatment with vitamin D. Q J Med. 1983;52(205):79-91.

46. Hoikka V, Alhava EM, Karjalainen P, et al. Carbamazepine and bone mineral metabolism. Acta Neurol Scand. 1984;70(2):77-80. doi:10.1111/j.1600-0404.1984.tb00806.x

47. Rajantie J, Lamberg-Allardt C, Wilska M. Does carbamazepine treatment lead to a need of extra vitamin D in some mentally retarded children? Acta Paediatr Scand. 1984;73(3):325-328.

48. Nishiyama S, Kuwahara T, Matsuda I. Decreased bone density in severely handicapped children and adults, with reference to the influence of limited mobility and anticonvulsant medication. Eur J Pediatr. 1986;144(5):457-463. doi:10.1007/BF00441738

49. Winnacker JL, Yeager H, Saunders JA, Russell B, Anast CS. Rickets in children receiving anticonvulsant drugs: biochemical and hormonal markers. Am J Dis Child. 1977;131(3):286-290. doi:10.1001/archpedi.1977.02120160040005

50. Markestad T, Ulstein M, Strandjord RE, Aksnes L, Aarskog D. Anticonvulsant drug therapy in human pregnancy: effects on serum concentrations of vitamin D metabolites in maternal and cord blood. Am J Obstet Gynecol. 1984;150(3):254-258. doi:10.1016/S0002-9378(84)90361-2

51. Riancho JA, Del Arco C, Arteaga R, Herranz JL, Albajar M, Macias JG. Influence of solar irradiation on vitamin D levels in children on anticonvulsant drugs. Acta Neurol Scand. 1989;79 (4):296-299. doi:10.1111/j.1600-0404.1989.tb03788.x

52. Hoikka V, Savolainen K, Alhava EM, Sivenius J, Karjalainen P, Parvianinen M. Anticonvulsant osteomalacia in epileptic outpatients. Ann Clin Res. 1982;14(3):129-132.

53. Bell RD, Pak CY, Zerwekh J, et al. Effect of phenytoin on bone and mineral density in ambulatory epileptic children. Brain Dev. 1994;16:382-385. doi:10.1016/0387-7604(94)90125-2

54. Collins N, Maher J, Cole M, et al. A prospective study to evaluate the dose of vitamin D required to correct low 25-hydroxyvitamin $\mathrm{D}$ levels, calcium, and alkaline phosphatase in patients at risk of developing antiepileptic drug-induced osteomalacia. $Q \mathrm{~J} \mathrm{Med}$. 1991;78:113-122.

55. Young RC, Blass JP. Iatrogenic nutritional deficiencies. Annu Rev Nutr. 1982;2:201-227. doi:10.1146/annurev.nu.02.070182.001221

56. Livingston S, Pauli LL. Anticonvulsants and rickets-a different view. Pediatrics. 1976;57(6):979.

57. Offermann G, Pinto V, Kruse R. Antiepileptic drugs and vitamin D supplementation. Epilepsia. 1979;20(1):3-15. doi:10.1111/ j.1528-1157.1979.tb04771.x

58. Peterson P, Gray P, Tolman KG. Calcium balance in drug-induced osteomalacia: response to vitamin D. Clin Pharmacol Ther. 1976;19(1):63-67. doi:10.1002/cpt197619163

59. Christiansen C, Rodbro P, Munck O. Actions of vitamins D2 and D3 and 25-OHD3 in anticonvulsant osteomalacia. $\mathrm{Br}$ Med $\mathrm{J}$. 1975;2(5967):363-365. doi:10.1136/bmj.2.5967.363

60. Menon B, Harinarayan CV. The effect of anti epileptic drug therapy on serum 25-hydroxyvitamin D and parameters of calcium and bone metabolism-A longitudinal study. Seizure. 2010;19(3):153-158. doi:10.1016/j.seizure.2010.01.006

61. Robien K, Oppeneer SJ, Kelly JA, Hamilton-Reeves JM. Drugvitamin D interactions: a systematic review of the literature. Nutr Clin Pract. 2013;28:194-208. doi:10.1177/0884533612467824

62. Mikati MA, Dib L, Yamout B, Sawaya R, Rahi AC, Fuleihan GE. Two randomized vitamin $\mathrm{D}$ trials in ambulatory patients on anticonvulsants: impact on bone. Neurology. 2006;67(11):2005-2014. doi:10.1212/01.wnl.0000247107.54562.0e
63. Jette N, Lix LM, Metge CJ, Prior HJ, McChesney J, Leslie WD. Association of antiepileptic drugs with nontraumatic fractures: a population-based analysis. Arch Neurol. 2011;68:107-112. doi:10.1001/archneurol.2010.341

64. Lee RH, Lyles KW, Sloane R, Colón-Emeric C. The association of newer anticonvulsant medications and bone mineral density. Endocr Pract. 2012;1-22. doi:10.4158/EP12119.OR

65. Bauer S, Hofbauer LC, Rauner M, et al. Early detection of bone metabolism changes under different antiepileptic drugs (EDBoM-AED) - a prospective multicenter study. Epilepsy Res. 2013;106:417-422. doi:10.1016/j.eplepsyres.2013.06.020

66. Beniczky SA, Viken J, Jensen LT, Andersen NB. Bone mineral density in adult patients treated with various antiepileptic drugs. Seizure. 2012;21:471-472. doi:10.1016/j.seizure.2012.04.002

67. Koo DL, Hwang KJ, Han SW, et al. Effect of oxcarbazepine on bone mineral density and biochemical markers of bone metabolism in patients with epilepsy. Epilepsy Res. 2014;108:442-447. doi:10.1016/j.eplepsyres.2013.09.009

68. Meier C, Kraenzlin ME. Antiepileptics and bone health. Ther Adv Musculoskelet Dis. 2011;3:235-243. doi:10.1177/ 1759720X11410769

69. Mintzer S, Boppana P, Toguri J, DeSantis A. Vitamin D levels and bone turnover in epilepsy patients taking carbamazepine or oxcarbazepine. Epilepsia. 2006;47:510-515. doi:10.1111/j.15281167.2006.00460.x

70. Phabphal K, Geater A, Limapichat K, Sathirapanya P, Setthawatcharawanich S, Leelawattana R. Effect of switching hepatic enzyme-inducer antiepileptic drug to levetiracetam on bone mineral density, 25 hydroxyvitamin D, and parathyroid hormone in young adult patients with epilepsy. Epilepsia. 2013;54:e94-8. doi:10.1111/epi.12162

71. Nissen-Meyer LS, Svalheim S, Tauboll E, et al. Levetiracetam, phenytoin, and valproate act differently on rat bone mass, structure, and metabolism. Epilepsia. 2007;48:1850-1860. doi:10.1111/j.1528-1167.2007.01176.x

72. Wu F-J, Sheu SY, Lin HC. Osteoporosis is associated with antiepileptic drugs: a population-based study. Epileptic Disord. 2014;16(3):333-342. doi:10.1684/epd.2014.0673

73. Frier BM, Scott RD. Osteomalacia and arthropathy associated with prolonged abuse of purgatives. $\mathrm{Br} J$ Clin Pract. 1977;31:17-19.

74. Boucher BJ. Inadequate vitamin D status: does it contribute to the disorders comprising syndrome ' $\mathrm{X}$ '? Br J Nutr. 1998;79(4):315327. doi:10.1079/BJN19980055

75. Takiishi T, Gysemans C, Bouillon R, Mathieu C. Vitamin D and diabetes. Endocrinol Metab Clin North Am. 2010;39:419-446.

76. Sohl E, Van Schoor NM, De Jongh RT, et al. The impact of medication on vitamin D status in older individuals. Eur $J$ Endocrinol. 2012;166:477-485. doi:10.1530/EJE-11-0917

77. Kos E, Liszek MJ, Emanuele MA, et al. Effect of metformin therapy on vitamin D and vitamin B12 levels in patients with type 2 diabetes mellitus. Endocr Pract. 2012;18(2):179-184. doi:10.4158/EP11009.OR

78. Suzuki A, Kotake M, Ono Y, et al. Hypovitaminosis D in type 2 diabetes mellitus: association with microvascular complications and type of treatment. Endocr J. 2006;53(4):503510. doi:10.1507/endocrj.k06-001

79. Ernst JB, Kuhn J, Becker T, et al. Association between circulating 25-hydroxyvitamin D levels and medication use in patients scheduled for cardiac surgery. Nutr Metab Cardiovasc Dis. 2015;25 (3):280-286. doi:10.1016/j.numecd.2014.10.014

80. van Orten-Luiten AC, Janse A, Dhonukshe-Rutten RA, Witkamp RF. Vitamin D deficiency as adverse drug reaction? A cross-sectional study in Dutch geriatric outpatients. Eur J Clin Pharmacol. 2016;72(5):605-614. doi:10.1007/s00228-0162016-2 
81. Lecka-Czernik B. Bone as a target of type 2 diabetes treatment. Curr Opin Investig. 2009;10:1085-1090.

82. Lecka-Czernik B. Bone loss in diabetes: use of antidiabetic thiazolidinediones and secondary osteoporosis. Curr Osteoporos Rep. 2010;8:178-184. doi:10.1007/s11914-010-0027-y

83. Habib ZA, Havstad SL, Wells K, Divine G, Pladevall M, Williams LK. Thiazolidinedione use and the longitudinal risk of fractures in patients with type 2 diabetes mellitus. $J$ Clin Endocrinol Metab. 2010;95(2):592-600. doi:10.1210/jc.20091385

84. Solomon DH, Cadarette SM, Choudhry NK, Canning C, Levin R, Sturmer T. A cohort study of thiazolidinediones and fractures in older adults with diabetes. J Clin Endocrinol Metab. 2009;94 (8):2792-2798. doi:10.1210/jc.2008-2157

85. Schwartz AV, Chen H, Ambrosius WT, et al. Effects of TZD use and discontinuation on fracture rates in ACCORD bone study. $J$ Clin Endocrinol Metab. 2015;100(11):4059-4066. doi:10.1210/ jc.2015-1215

86. Benvenuti S, Cellai I, Luciani P, et al. Rosiglitazone stimulates adipogenesis and decreases osteoblastogenesis in human mesenchymal stem cells. J Endocrinol Invest. 2007;30(9): RC26-30. doi:10.1007/BF03350807

87. Ali AA, Weinstein RS, Stewart SA, Parfitt AM, Manolagas SC, Jilka RL. Rosiglitazone causes bone loss in mice by suppressing osteoblast differentiation and bone formation. Endocrinology. 2005;146(3):1226-1235. doi:10.1210/en.2004-0735

88. Billington EO, Grey A, Bolland MJ. The effect of thiazolidinediones on bone mineral density and bone turnover: systematic review and meta-analysis. Diabetologia. 2015;58(10):2238-2246. doi:10.1007/s00125-015-3660-2

89. Loke YK, Singh S, Furberg CD. Long-term use of thiazolidinediones and fractures in type 2 diabetes: a meta-analysis. Cmaj. 2009;180(1):32-39. doi:10.1503/cmaj.080486

90. Zabłocka-Słowińska K, Dzielska E, Gryszkin I, Grajeta H. Dietary supplementation during diabetes therapy and the potential risk of interactions. Adv Clin Exp Med. 2014;23(6):939-946. doi: $10.17219 /$ acem $/ 37348$

91. Rejnmark L, Vestergaard P, Heickendorff L, et al. Effects of thiazide- and loop-diuretics, alone or in combination, on calcitropic hormones and biochemical bone markers: a randomized controlled study. J Intern Med. 2001;250(2):144-153.

92. Hathcock JN, Shao A, Vieth R, Heaney R. Risk assessment for vitamin D. Am J Clin Nutr. 2007;85(1):6-18. doi:10.1093/ajen/ 85.1.6

93. Riis B, Christiansen C. Actions of thiazide on vitamin D metabolism: a controlled therapeutic trial in normal women early in the postmenopause. Metab Clin Exp. 1985;34(5):421-424. doi:10.1016/0026-0495(85)90206-9

94. Lemann J, Gray RW, Maierhofer WJ, Cheung HS. Hydrochlorothiazide inhibits bone resorption in men despite experimentally elevated serum 1,25-dihydroxyvitamin D concentrations. Kidney Int. 1985;28(6):951-958. doi:10.1038/ ki. 1985.223

95. Kokot F, Pietrek J, Srokowska S, et al. 25-Hydroxyvitamin D in patients with essential hypertension. Clin Nephrol. 1981;16 (4):188-192.

96. Perry HM, Jensen J, Kaiser FE, Horowitz M, Perry HM, Morley JE. The effects of thiazide diuretics on calcium metabolism in the aged. J Am Geriatr Soc. 1993;41(8):818-822. doi:10.1111/j.15325415.1993.tb06176.x

97. Rejnmark L, Vestergaard P, Heickendorff L, Andreasen F, Mosekilde L. Effects of long-term treatment with loop diuretics on bone mineral density, calcitropic hormones and bone turnover. $J \quad$ Intern Med. 2005;257:176-184. doi:10.1111/j.13652796.2004.01434.x
98. Lips P. Vitamin D deficiency and secondary hyperparathyroidism in the elderly: consequences for bone loss and fractures and therapeutic implications. Endocr Rev. 2001;22:477-501. doi:10.1210/edrv.22.4.0437

99. Levin TT, Bakr MH, Nikolova T. Case report: delirium due to a diltiazem-fentanyl CYP3A4 drug interaction. Gen Hosp Psychiatry. 2010;32:648. doi:10.1016/j.genhosppsych.2010.08.003

100. Zhou SF, Xue CC, Yu XQ, et al. Clinically important drug interactions potentially involving mechanism-based inhibition of cytochrome P450 3A4 and the role of therapeutic drug monitoring. Ther Drug Monit. 2007;29(6):687-710. doi:10.1097/ FTD.0b013e31815c16f5

101. Grober U, Kisters K. Influence of drugs on vitamin D and calcium metabolism. Dermatoendocrinol. 2012;4(2):158-166. doi:10.4161/derm.20731

102. Perez-Castrillon JL, Justo I, Sanz A, et al. Effect of angiotensin converting enzyme inhibitors on 1,25- $(\mathrm{OH}) 2 \mathrm{D}$ levels of hypertensive patients. Relationship with ACE polymorphisms. Horm Metab Res. 2006;38(12):812-816. doi:10.1055/s-2006-956500

103. Semba RD, Bartali B, Zhou J, Blaum C, Ko CW, Fried LP. Low serum micronutrient concentrations predict frailty among older women living in the community. J Gerontol A Biol Sci Med Sci. 2006;61(6):594-599. doi:10.1093/gerona/61.6.594

104. Vogt S, Decke S, de Las Heras Gala T, et al. Prospective association of vitamin $\mathrm{D}$ with frailty status and all-cause mortality in older adults: results from the KORA-age study. Prev Med. 2015;1 (73):40-46. doi:10.1016/j.ypmed.2015.01.010

105. Pérez-Castrillón JL, Vega G, Abad L, et al. Effects of atorvastatin on vitamin $\mathrm{D}$ levels in patients with acute ischemic heart disease. Am J Cardiol. 2007;99(7):903-905.

106. Perez-Castrillon JL, Silva J, Justo I, et al. Effect of quinapril, quinapril-hydrochlorothiazide, and enalapril on the bone mass of hypertensive subjects: relationship with angiotensin converting enzyme polymorphisms. Am J Hypertens. 2003;16(6):453-459. doi:10.1016/S0895-7061(03)00845-8

107. Forouhi NG, Ye Z, Rickard AP, et al. Circulating 25-hydroxyvitamin D concentration and the risk of type 2 diabetes: results from the European Prospective Investigation into Cancer (EPIC)Norfolk cohort and updated meta-analysis of prospective studies. Diabetologia. 2012;55(8):2173-2182. doi:10.1007/s00125-0122544-y

108. Istvan ES, Deisenhofer J. Structural mechanism for statin inhibition of HMG-CoA reductase. Science. 2001;292(5519):11601164. doi:10.1126/science. 1059344

109. Dobs AS, Levine MA, Margolis S. Effects of pravastatin, a new HMGCoA reductase inhibitor, on vitamin D synthesis in man. Metabolism. 1991;40(5):524-528. doi:10.1016/0026-0495(91) 90235-O

110. Montagnani M, Lore F, Di Cairano G, et al. Effects of pravastatin treatment on vitamin D metabolites. Clin Ther. 1994;16(5):824829.

111. Vaughan CJ, Gotto AM. Update on statins: 2003. Circulation. 2004;110(7):886-892. doi:10.1161/01.CIR.0000139312.10076. BA

112. Williams D, Feely J. Pharmacokinetic-pharmacodynamic drug interactions with HMG-CoA reductase inhibitors. Clin Pharmacokinet. 2002;41(5):343-370. doi:10.2165/00003088200241050-00003

113. Neuvonen PJ, Niemi M, Backman JT. Drug interactions with lipidlowering drugs: mechanisms and clinical relevance. Clin Pharmacol Ther. 2006;80(6):565-581. doi:10.1016/j. clpt.2006.09.003

114. Schwartz JB. Effects of vitamin D supplementation in atorvastatin-treated patients: a new drug interaction with an unexpected consequence. Clin Pharmacol Ther. 2009;85(2):198-203. doi:10.1038/clpt.2008.165 
115. Aloia JF, Li-Ng M, Pollack S. Statins and vitamin D. Am $J$ Cardiol. 2007;100(8):1329. doi:10.1016/j.amjcard.2007.05.024

116. Ismail F, Corder CN, Epstein S, Barbi G, Thomas S. Effects of pravastatin and cholestyramine on circulating levels of parathyroid hormone and vitamin D metabolites. Clin Ther. 1990;12 (5):427-430.

117. Ridker PM, Glynn RJ. Rosuvastatin, C-reactive protein, LDL cholesterol, and the JUPITER trial-Authors' reply. Lancet. 2009;374:26-27. doi:10.1016/S0140-6736(09)61234-4

118. Yavuz B, Ertugrul DT, Cil H, et al. Increased levels of 25 hydroxyvitamin D and 1,25-dihydroxyvitamin D after rosuvastatin treatment: a novel pleiotropic effect of statins? Cardiovasc Drugs Ther. 2009;23 (4):295-299. doi:10.1007/s10557-009-6181-8

119. Ertugrul DT, Yavuz B, Cil H, et al. STATIN-D Study: comparison of the influences of rosuvastatin and fluvastatin treatment on the levels of 25 hydroxyvitamin D. Cardiovasc Ther. 2011;29 (2):146-152. doi:10.1111/j.1755-5922.2010.00141.x

120. Glossmann HH, Blumthaler M. Does rosuvastatin increase serum levels of 25-hydroxy-vitamin D? Dermato-endocrinology. 2012;4 (1):2-7. doi:10.4161/derm.18681

121. Holick MF. The statin D-lemma. Dermato-Endocrinology. 2012;4 (1):10-11. doi:10.4161/derm.20189

122. Sahebkar A, Reiner Ž, E Simental-Mendía L, et al. Impact of statin therapy on plasma vitamin D levels: a systematic review and meta-analysis. Curr Pharm Des. 2017;23(6):861-869. doi:10.2174/1381612822666161006150542

123. Yavuz B, Ertugrul DT. Statins and vitamin D: a hot topic that will be discussed for a long time. Dermato-Endocrinology. 2012;4 (1):8-9. doi:10.4161/derm.20188

124. Ahmed W, Khan N, Glueck CJ, et al. Low serum $25(\mathrm{OH})$ vitamin D levels $(<32 \mathrm{ng} / \mathrm{mL})$ are associated with reversible myositismyalgia in statin-treated patients. Transl Res. 2009;153:11-16.

125. Plotnikoff GA, Quigley JM. Prevalence of severe hypovitaminosis D in patients with persistent, nonspecific musculoskeletal pain. Mayo Clin Proc. 2003;78(12):1463-1470. doi:10.4065/ 78.12 .1463

126. Glueck CJ, Budhani SB, Masineni SS, et al. Vitamin D deficiency, myositis-myalgia, and reversible statin intolerance. Curr Med Res Opin. 2011;27(9):1683-1690. doi:10.1185/ 03007995.2011.598144

127. Michalska-Kasiczak M, Sahebkar A, Mikhailidis DP, et al. Analysis of vitamin D levels in patients with and without statinassociated myalgia - a systematic review and meta-analysis of 7 studies with 2420 patients. Int $J$ Cardiol. 2015;178:111-116. doi:10.1016/j.ijcard.2014.10.118

128. Tonstad S, Knudtzon J, Sivertsen M, Refsum H, Ose L. Efficacy and safety of cholestyramine therapy in peripubertal and prepubertal children with familial hypercholesterolemia. J Pediatr. 1996;129(1):42-49. doi:10.1016/S0022-3476(96)70188-9

129. Knodel LC, Talbert RL. Adverse effects of hypolipidaemic drugs. Med Toxicol. 1987;2:10-32. doi:10.1007/BF03259858

130. Compston JE, Horton LW. Oral 25-hydroxyvitamin D3 in treatment of osteomalacia associated with ileal resection and cholestyramine therapy. Gastroenterology. 1978;74:900-902. doi:10.1016/0016-5085(78)90150-6

131. Compston JE, Thompson RP. Intestinal absorption of 25-hydroxyvitamin D and osteomalacia in primary biliary cirrhosis. Lancet. 1977;1:721-724. doi:10.1016/S0140-6736(77)92167-5

132. Heaton KW, Lever JV, Barnard RE. Osteomalacia associated with cholestyramine therapy for post-ileectomy diarrhea. Gastroenterology. 1972;62:642-646. doi:10.1016/S0016-5085 (72)80051-9

133. Hoogwerf BJ, Hibbard DM, Hunninghake DB. Effects of longterm cholestyramine administration on vitamin $\mathrm{D}$ and parathormone levels in middle-aged men with hypercholesterolaemia. $J$ Lab Clin Med. 1992;119:407-411.
134. Schwarz KB, Goldstein PD, Witztum JL, Schonfeld G. Fat-soluble vitamin concentrations in hypercholesterolemic children treated with colestipol. Pediatrics. 1980;65(2):243-250. doi:10.1542/ peds.65.2.243

135. Tsang RC, Roginsky MS, Mellies MJ, Glueck CJ. Plasma 25hydroxy-vitamin $\mathrm{D}$ in familial hypercholesterolemic children receiving colestipol resin. Pediatr Res. 1978;12(10):980-982. doi:10.1203/00006450-197810000-00006

136. Senova E, Steno B, Killinger Z, Baqi L, Payer J. Effect of longterm oral anticoagulant therapy on bone mineral density and bone turnover markers: a prospective 12 month study. Bratisl Lek Listy. 2011;112(2):71-76.

137. Avgeri M, Papadopoulou A, Platokouki H, et al. Assessment of bone mineral density and markers of bone turnover in children under longterm oral anticoagulant therapy. J Pediatr Hematol Oncol. 2008;30 (8):592-597. doi:10.1097/MPH.0b013e31817541a8

138. Sato Y, Honda Y, Kunoh H, Oizumi K. Long-term oral anticoagulation reduces bone mass in patients with previous hemispheric infarction and nonrheumatic atrial fibrillation. Stroke. 1997;28(12):2390-2394. doi:10.1161/01.STR.28.12.2390

139. Sato Y, Honda Y, Jun I. Long-term oral anticoagulation therapy and the risk of hip fracture in patients with previous hemispheric infarction and nonrheumatic atrial fibrillation. Cerebrovasc Dis. 2009;29(1):73. doi:10.1159/000256650

140. Vestergaard P, Hermann P, Jensen JE, Eiken P, Mosekilde L. Effects of paracetamol, non-steroidal anti-inflammatory drugs, acetylsalicylic acid, and opioids on bone mineral density and risk of fracture: results of the Danish Osteoporosis Prevention Study (DOPS). Osteoporos Int. 2012;23(4):1255-1265. doi:10.1007/s00198-011-1692-0

141. Cigolini M, Iagulli MP, Miconi V, Galiotto M, Lombardi S, Targher G. Serum 25-hydroxyvitamin D3 concentrations and prevalence of cardiovascular disease among type 2 diabetic patients. Diabetes Care. 2006;29(3):722-724. doi:10.2337/diacare.29.03.06.dc05-2148

142. Verhoeven V, Vanpuyenbroeck K, Lopez-Hartmann M, et al. Walk on the sunny side of life-epidemiology of hypovitaminosis $\mathrm{D}$ and mental health in elderly nursing home residents. $J$ Nutr Health Aging. 2012;16(4):417-420. doi:10.1007/s12603-0110361-5

143. Milaneschi Y, Hoogendijk W, Lips P, et al. The association between low vitamin $\mathrm{D}$ and depressive disorders. $\mathrm{Mol}$ Psychiatry. 2014;19:444-451.

144. Chonan O, Takahashi R, Yasui H, Watanuki M. Effect of L-lactic acid on calcium absorption in rats fed omeprazole. J Nutr Sci Vitaminol. 1998;44:473-481. doi:10.3177/jnsv.44.473

145. O' Connel MB, Madden DM, Murray AM, Heaney RP, Kerzner LJ. Effects of proton pump inhibitors on calcium carbonate absorption in women: a randomized crossover trial. Am J Med. 2005;118:778-781. doi:10.1016/j.amjmed.2005.02.007

146. Teramura-Grönblad M, Hosia-Randell H, Muurinen S, Pitkala K. Use of proton-pump inhibitors and their associated risks among frail elderly nursing home residents. Scand J Prim Health Care. 2010;28:154-159. doi:10.3109/02813432.2010.493315

147. Bengoa JM, Bolt MJ, Rosenberg IH. Hepatic vitamin D 25hydroxylase inhibition by cimetidine and isoniazid. $J$ Lab Clin Med. 1984;104(4):546-552.

148. Wyatt CL, Jensen LS, Rowland GN. Effect of cimetidine on eggshell quality and plasma 25-hydroxycholecalciferol in laying hens. Poult Sci. 1990;69(11):1892-1899. doi:10.3382/ps.0691892

149. Odes HS, Fraser GM, Krugliak P, Lamprecht SA, Shany S. Effect of cimetidine on hepatic vitamin D metabolism in humans. Digestion. 1990;46(2):61-64. doi:10.1159/000200333

150. Richards DA. Comparative pharmacodynamics and pharmacokinetics of cimetidine and ranitidine. J Clin Gastroenterol. 1983;5 (suppl 1):81-90. doi:10.1097/00004836-198312001-00008 
151. Rickers H, Deding A, Christiansen C, Rodbro P, Naestoft J. Corticosteroid- induced osteopenia and vitamin D metabolism: effect of vitamin D2, calcium phosphate and sodium fluoride administration. Clin Endocrinol. 1982;16(4):409-415. doi:10.1111/j.1365-2265.1982.tb00734.x

152. Zerwekh JE, Emkey RD, Harris ED. Low-dose prednisone therapy in rheumatoid arthritis: effect on vitamin D metabolism. Arthritis Rheum. 1984;27(9):1050-1052. doi:10.1002/ art. 1780270913

153. Hahn TJ, Halstead LR, Baran DT. Effects of short term glucocorticoid administration on intestinal calcium absorption and circulating vitamin D metabolite concentrations in man. J Clin Endocrinol Metab. 1981;52(1):111-115. doi:10.1210/jcem-52-1111

154. Prummel MF, Wiersinga WM, Lips P, Sanders GT, Sauerwein HP. The course of biochemical parameters of bone turnover during treatment with corticosteroids. J Clin Endocrinol Metab. 1991;72 (2):382-386. doi:10.1210/jcem-72-2-382

155. Lems WF, Jacobs JW, Van Rijn HJ, Bijlsma JW. Changes in calcium and bone metabolism during treatment with low dose prednisone in young, healthy, male volunteers. Clin Rheumatol. 1995;14(4):420-424. doi:10.1007/BF02207675

156. Halton JM, Atkinson SA, Fraher L, et al. Altered mineral metabolism and bone mass in children during treatment for acute lymphoblastic leukemia. J Bone Miner Res. 1996;11(11):17741783. doi:10.1002/jbmr.5650111122

157. Hahn TJ, Halstead LR, Haddad JG. Serum 25-hydroxyvitamin D concentrations in patients receiving chronic corticosteroid therapy. J Lab Clin Med. 1977;90(2):399-404.

158. Klein RG, Arnaud SB, Gallagher JC, Deluca HF, Riggs BL. Intestinal calcium absorption in exogenous hypercortisonism: role of 25-hydroxyvitamin $\mathrm{D}$ and corticosteroid dose. J Clin Invest. 1977;60(1):253-259. doi:10.1172/JCI108762

159. Lund B, Storm TL, Melsen F, et al. Bone mineral loss, bone histomorphometry and vitamin $\mathrm{D}$ metabolism in patients with rheumatoid arthritis on longterm glucocorticoid treatment. Clin Rheumatol. 1985;4(2):143-149. doi:10.1007/BF02032284

160. Bikle DD, Halloran B, Fong L, Steinbach L, Shellito J. Elevated 1,25-dihydroxyvitamin D levels in patients with chronic obstructive pulmonary disease treated with prednisone. J Clin Endocrinol Metab. 1993;76(2):456-461.

161. Wetzsteon RJ, Shults J, Zemel BS, et al. Divergent effects of glucocorticoids on cortical and trabecular compartment BMD in childhood nephrotic syndrome. J Bone Miner Res. 2009;24 (3):503-513. doi:10.1359/jbmr.081101

162. Wolthers OD, Riis BJ, Pedersen S. Bone turnover in asthmatic children treated with oral prednisolone or inhaled budesonide. Pediatr Pulmonol. 1993;16(6):341-346. doi:10.1002/ ppul.1950160604

163. Bijlsma JW, Duursma SA, Huber-Bruning O. Bone metabolism during methylprednisolone pulse therapy in rheumatoid arthritis. Ann Rheum Dis. 1986;45(9):757-760. doi:10.1136/ard.45.9.757

164. Slovik DM, Neer RM, Ohman JL, et al. Parathyroid hormone and 25-hydroxyvitamin D levels in glucocorticoid-treated patients. Clin Endocrinol. 1980;12(3):243-248. doi:10.1111/j.13652265.1980.tb02706.x

165. Als OS, Riis B, Christiansen C. Serum concentration of vitamin D metabolites in rheumatoid arthritis. Clin Rheumatol. 1987;6 (2):238-243. doi:10.1007/BF02201030

166. von Scheven E, Gordon CM, Wypij D, Wertz M, Gallagher KT, Bachrach L. Variable deficits of bone mineral despite chronic glucocorticoid therapy in pediatric patients with inflammatory diseases: a Glaser Pediatric Research Network study. J Pediatr Endocrinol Metab. 2006;19(6):821-830. doi:10.1515/ JPEM.2006.19.6.821
167. Sentongo TA, Semaeo EJ, Stettler N, Piccoli DA, Stallings VA, Zemel BS. Vitamin D status in children, adolescents, and young adults with Crohn disease. Am J Clin Nutr. 2002;76(5):10771081. doi:10.1093/ajcn/76.5.1077

168. Cohran VC, Griffiths M, Heubi JE. Bone mineral density in children exposed to chronic glucocorticoid therapy. Clin Pediatr. 2008;47(5):469-475. doi:10.1177/0009922807311732

169. Santiago RA, Silva CA, Caparbo VF, Sallum AM, Pereira RM. Bone mineral apparent density in juvenile dermatomyositis: the role of lean body mass and glucocorticoid use. Scand $J$ Rheumatol. 2008;37(1):40-47. doi:10.1080/03009740701687226

170. Jennings BH, Andersson KE, Johansson SA. The assessment of the systemic effects of inhaled glucocorticosteroids. The effects of inhaled budesonide vs oral prednisolone on calcium metabolism. Eur J Clin Pharmacol. 1991;41:11-16. doi:10.1007/ BF00280099

171. Janssens W, Bouillon R, Claes B, et al. Vitamin D deficiency is highly prevalent in COPD and correlates with variants in the vitamin D-binding gene. Thorax. 2010;65:215-220. doi:10.1136/ thx.2009.120659

172. Kunisaki KM, Rector TS. Vitamin D and responses to inhaled fluticasone in severe chronic obstructive pulmonary disease. Int J Chron Obstruct Pulmon Dis. 2011;6:29-34. doi:10.2147/COPD. $\mathrm{S} 15358$

173. Richy F, Bousquet J, Ehrlich GE, et al. Inhaled corticosteroids effects on bone in asthmatic and COPD patients: a quantitative systematic review. Osteoporos Int. 2003;14(3):179-190. doi:10.1007/s00198-003-1398-z

174. Jones A, Fay JK, Burr ML, Stone M, Hood K, Roberts G. Inhaled corticosteroid effects on bone metabolism in asthma and mild chronic obstructive pulmonary disease. Cochrane Database Syst Rev.

175. Halpern MT, Schmier JK, Van Kerkhove MD, Watkins M, Kalberg CJ. Impact of long-term inhaled corticosteroid therapy on bone mineral density: results of a meta-analysis. Ann Allergy Asthma Immunol. 2004;92(2):201-207. doi:10.1016/S1081-1206 (10)61548-7

176. Loke YK, Gilbert D, Thavarajah M, Blanco P, Wilson AM. Bone mineral density and fracture risk with long-term use of inhaled corticosteroids in patients with asthma: systematic review and meta-analysis. BMJ Open. 2015;5(11):e008554. doi:10.1136/ bmjopen-2015-008554

177. Vanfleteren LE, Spruit MA, Groenen M, et al. Clusters of comorbidities based on validated objective measurements and systemic inflammation in patients with chronic obstructive pulmonary disease. Am J Respir Crit Care Med. 2013;187(7):728-735. doi:10.1164/rccm.201209-1665OC

178. Weatherall M, James K, Clay J, et al. Dose-response relationship for risk of non-vertebral fracture with inhaled corticosteroids. Clin Exp Allerg. 2008;38(9):1451-1458. doi:10.1111/j.13652222.2008.03029.x

179. Loke YK, Cavallazzi R, Singh S. Risk of fractures with inhaled corticosteroids in COPD: systematic review and meta-analysis of randomised controlled trials and observational studies. Thorax. 2011;66:699-708. doi:10.1136/thx.2011.160028

180. Chan V, Cave AJ, Banh HL. Self-reported osteoporosis prevention in inhaled corticosteroid users in community pharmacy setting. SAGE Open Med. 2015;22(3):2050312115586912.

181. American College of Rheumatology Task Force on Osteoporosis Guidelines. Recommendations for the prevention and treatment of glucocorticoid-induced osteoporosis. Arthritis Rheum. 1996;39:1791-1801. doi:10.1002/art.1780391104

182. de Vries F, Pouwels S, Bracke M, et al. Use of beta-2 agonists and risk of hip/femur fracture: a population-based case-control study. Pharmacoepidemiol Drug Saf. 2007;16(6):612-619. doi:10.1002/ pds. 1318 
183. Tattersfield AE, Town GI, Johnell O, et al. Bone mineral density in subjects with mild asthma randomised to treatment with inhaled corticosteroids or non-corticosteroid treatment for two years. Thorax. 2001;56(4):272-278. doi:10.1136/thorax.56.4.272

184. Williams SE, Wardman AG, Taylor GA, et al. Long term study of the effect of rifampicin and isoniazid on vitamin D metabolism. Tubercle. 1985;66:49-54. doi:10.1016/0041-3879(85)90053-4

185. Kovacs CS, Jones G, Yendt ER. Primary hyperparathyroidism masked by antituberculous therapy-induced vitamin D deficiency. Clin Endocrinol. 1994;41:831-838. doi:10.1111/j.1365-2265.1994. tb02801.x

186. Perry W, Erooga MA, Brown J, Stamp TC. Calcium metabolism during rifampicin and isoniazid therapy for tuberculosis. $J R$ Soc Med. 1982;75:533-536.

187. Wanga Z. Interplay between vitamin D and the drug metabolizing enzyme CYP3A4. J Steroid Biochem Mol Biol. 2013;136:54-58. doi:10.1016/j.jsbmb.2012.09.012

188. Brodie MJ, Boobis AR, Dollery CT, et al. Rifampicin and vitamin D metabolism. Clin Pharmacol Ther. 1980;27(6):810-814. doi:10.1038/clpt.1980.115

189. Brodie MJ, Boobis AR, Hillyard CJ, Abeyasekera G, MacIntyre I, Park BK. Effect of isoniazid on vitamin D metabolism and hepatic monooxygenase activity. Clin Pharmacol Ther. 1981;30 (3):363-367. doi:10.1038/clpt.1981.173

190. Brodie MJ, Boobis AR, Hillyard CJ, et al. Effect of rifampicin and isoniazid on vitamin D metabolism. Clin Pharmacol Ther. 1982;32(4):525-530. doi:10.1038/clpt.1982.197

191. Davies PD, Brown RC, Church HA, Woodhead JS. The effect of antituberculosis chemotherapy on vitamin $\mathrm{D}$ and calcium metabolism. Tubercle. 1987;68(4):261-266. doi:10.1016/0041-3879(87)90066-3

192. Martinez ME, Gonzalez J, Sanchez-Cabezudo MJ, Pena JM, Vazquez JJ. Remission of hypercalciuria in patients with tuberculosis after treatment. Calcif Tissue Int. 1996;59(1):17-20. doi:10.1007/s002239900078

193. Shah SC, Sharma RK, Hemangini H, Chitle AR. Rifampicin induced osteomalacia. Tubercle. 1981;62:207-209. doi:10.1016/ 0041-3879(81)90008-8

194. Reitsma JB, Castro Cabezas M, de Bruin TW, Erkelens DW. Relationship between improved postprandial lipemia and lowdensity lipoprotein metabolism during treatment with tetrahydrolipstatin, a pancreatic lipase inhibitor. Metab Clin Exp. 1994;43 (3):293-298. doi:10.1016/0026-0495(94)90095-7

195. Guerciolini R. Mode of action of orlistat. Int J Obes Relat Metab Disord. 1997;21(suppl 3):S12.

196. Gotfredsen A, Westergren Hendel H, Andersen T. Influence of orlistat on bone turnover and body composition. Int J Obes Relat Metab Disord. 2001;25(8):1154-1160. doi:10.1038/sj.ijo.0801639

197. James WP, Avenell A, Broom J, Whitehead J. A one-year trial to assess the value of orlistat in the management of obesity. Int $J$ Obes Relat Metab Disord. 1997;21(suppl 3):S24-S30.

198. McDuffie JR, Calis KA, Booth SL, Uwaifo GI, Yanovski JA. Effects of orlistat on fat-soluble vitamins in obese adolescents. Pharmacotherapy. 2002;22(7):814-822. doi:10.1592/ phco.22.11.814.33627

199. Ruiz-Irastorza G, Egurbide MV, Olivares N, Martinez-Berriotxoa A, Aguirre C. Vitamin D deficiency in systemic lupus erythematosus: prevalence, predictors and clinical consequences. Rheumatology. 2008;47:920-923. doi:10.1093/rheumatology/ken121

200. Flexner C. Antiretroviral agents and treatment of HIV infection. In: Brunton LL, Lazo JS, Parker KL, editors. Goodman \& Gilman's the Pharmacological Basis of Therapeutics. 11th ed. New York: McGraw-Hill; 2006.

201. Cozzolino M, Vidal M, Arcidiacono MV, Tebas P, Yarasheski KE, Dusso AS. HIV-protease inhibitors impair vitamin D bioactivation to 1,25-dihydroxyvitamin D. AIDS. 2003;17(4):513-520. doi:10.1097/00002030-200303070-00006
202. Ramayo E, Gonzalez-Moreno MP, Macias J, et al. Relationship between osteopenia, free testosterone, and vitamin $\mathrm{D}$ metabolite levels in HIVinfected patients with and without highly active antiretroviral therapy. AIDS Res Hum Retroviruses. 2005;21 (11):915-921. doi:10.1089/aid.2005.21.915

203. Curtis JR, Smith B, Weaver M, et al. Ethnic variations in the prevalence of metabolic bone disease among HIV-positive patients with lipodystrophy. AIDS Res Hum Retroviruses. 2006;22(2):125-131. doi:10.1089/aid.2006.22.125

204. Garcia Aparicio AM, Munoz Fernandez S, Gonzalez J, et al. Abnormalities in the bone mineral metabolism in HIV-infected patients. Clin Rheumatol. 2006;25(4):537-539. doi:10.1007/ s10067-005-0028-x

205. Havers FP, Detrick B, Cardoso SW, et al. Change in Vitamin D levels occurs early after antiretroviral therapy initiation and depends on treatment regimen in resource-limited settings. PLoS One. 2014;9(4):e95164. doi:10.1371/journal.pone.0095164

206. Tannirandorn P, Epstein S. Drug-induced bone loss. Osteoporos Int. 2000;11:637-659. doi:10.1007/s001980070062

207. Zimran A, Shilo S, Fisher D, Bab I. Histomorphometric evaluation of reversible heparin-induced osteoporosis in pregnancy. Arch Intern Med. 1986;146:386-388. doi:10.1001/ archinte. 1986.00360140226033

208. Dahlman TC. Osteoporotic fractures and the recurrence of thromboembolism during pregnancy and the puerperium in 184 women undergoing thromboprophylaxis with heparin. Am J Obstet Gynecol. 1993;168:1265-1270. doi:10.1016/0002-9378(93)90378-V

209. Barbour LA, Kick SD, Steiner JF, et al. A prospective study of heparin-induced osteoporosis in pregnancy using bone densitometry. Am J Obstet Gynecol. 1994;170:862-869. doi:10.1016/ S0002-9378(94)70299-3

210. Martineau P, Tawil N. Low-molecular-weight heparins in the treatment of deep-vein thrombosis. Ann Pharmacother. 1998;32:588-98,601. doi:10.1345/aph.16450

211. Aarskog D, Aksnes L, Lehmann V. Low 1,25-dihydroxyvitamin $\mathrm{D}$ in heparin-induced osteopenia (letter). Lancet. 1980;2:650-651. doi:10.1016/S0140-6736(80)90325-6

212. Monreal M, Olive A, Lafoz E, Del Rio L. Heparins, coumarin and bone density (letter). Lancet. 1991;338:706. doi:10.1016/01406736(91)91292-3

213. Pettila V, Leinonen P, Markkola A, et al. Postpartum bone mineral density in women treated for thromboprophylaxis with unfractionated heparin or LMW heparin. Thromb Haemost. 2002;87:182186. doi:10.1055/s-0037-1612970

214. Sivakumaran M, Ghosh K, Zaidi Y, Hutchinson RM. Osteoporosis and vertebral collapse following low-dose, low molecular weight heparin therapy in a young patient. Clin Lab Haematol. 1996;18:55-57. doi:10.1111/j.1365-2257.1996.tb00741.x

215. Meijerman I, Beijnen JH, Schellens JH. Herb-drug interactions in oncology: focus on mechanisms of induction. Oncologist. 2006;11(7):742-752. doi:10.1634/theoncologist.11-7-742

216. Santini D, Galluzzo S, Vincenzi B, et al. A longitudinal evaluation of vitamin D plasma levels during anthracycline- and docetaxel-based adjuvant chemotherapy in early-stage breast cancer patients. Ann Oncol. 2010;21(1):185-186. doi:10.1093/annonc/ mdp497

217. Freedman DM, Looker AC, Chang SC, et al. Prospective study of serum vitamin D and cancer mortality in the United States. J Natl Cancer Inst. 2007;99:1594-1602. doi:10.1093/jnci/djm204

218. Kailajarvi ME, Salminen EK, Paija OM, et al. Serum bone markers in breast cancer patients during 5-fluorouracil, epirubicin and cyclophosphamide (FEC) therapy. Anticancer Res. 2004;24:1271-1274.

219. Crew KD, Shane E, Cremers S, et al. High prevalence of vitamin D deficiency despite supplementation in premenopausal women with breast cancer undergoing adjuvant chemotherapy. J Clin Oncol. 2009;27:2151-2156. doi:10.1200/JCO.2008.19.6162 
220. Jacot W, Pouderoux S, Thezenas S. Increased prevalence of vitamin D insufficiency in patients with breast cancer after neoadjuvant chemotherapy. Breast Cancer Res Treat. 2012;134:709717. doi:10.1007/s10549-012-2084-7

221. Goodwin PJ, Ennis M, Pritchard KI, et al. Prognostic effects of 25-hydroxyvitamin D levels in early breast cancer. J Clin Oncol. 2009;27:3757-3763. doi:10.1200/JCO.2008.20.0725

222. Gao Y, Shimizu M, Yamada S, Ozaki Y, Aso T. The effects of chemotherapy including cisplatin on vitamin D metabolism. Endocr J. 1993;40(6):737-742. doi:10.1507/endocrj.40.737

223. Fakih MG, Trump DL, Johnson CS, Tian L, Muindi J, Sunga AY. Chemotherapy is linked to severe vitamin D deficiency in patients with colorectal cancer. Int J Colorectal Dis. 2009;24(2):219-224. doi:10.1007/s00384-008-0593-y

224. Matsuoka LY, Ide L, Wortsman J, et al. Suncreens suppress cutaneous vitamin D3 synthesis. J Clin Endocrinol Metab. 1987;64:1165-1168. doi:10.1210/jcem-64-6-1165

225. Matsuoka LY, Wortsman J, Hanifan N, Holick MF. Chronic suncreen use decreases circulating concentrations of 25-hydroxyvitamin D. Arch Dermatol. 1988;124:1802-1804. doi:10.1001/ archderm.1988.01670120018003

226. Prystowsky JH. Photoprotection and the vitamin D status of the elderly. Arch Dermatol. 1988;124:1844-1848. doi:10.1001/ archderm.1988.01670120060011

227. Holick MF. Sunlight "D"ilemma: risk of skin cancer or bone disease and muscle weakness. Lancet. 2001;357:4-6. doi:10.1016/S0140-6736(00)03560-1

228. Reichrath J. Protecting against adverse effects of sun protection. $J$ Am Acad Dermatol. 2003;49:1204-1206. doi:10.1016/S01909622(03)02142-X

229. Huang $H$, Wang $H$, Sinz $M$, et al. Inhibition of drug metabolism by blocking the activation of nuclear receptors by ketoconazole. Oncogene. 2007;26(2):258-268. doi:10.1038/sj.onc.1209788

230. Marechal JD, Yu J, Brown S, et al. In silico and in vitro screening for inhibition of cytochrome P450 CYP3A4 by comedications commonly used by patients with cancer. Drug Metab Dispos. 2006;34(4):534-538. doi:10.1124/dmd.105.007625

231. Loose DS, Kan PB, Hirst MA, Marcus RA, Feldman D. Ketoconazole blocks adrenal steroidogenesis by inhibiting cytochrome P450-dependent enzymes. J Clin Invest. 1983;71 (5):1495-1499. doi:10.1172/JCI110903

232. Kassi EN, Stavropoulos S, Kokkoris P, et al. Smoking is a significant determinant of low serum vitamin $\mathrm{D}$ in young and middle-aged healthy males. Hormones. 2015;14(2):245-250.

233. Jaaskelainen T, Knekt P, Marniemi J, et al. Vitamin D status is associated with sociodemographic factors, lifestyle and metabolic health. Eur J Nutr. 2013;52:513-525. doi:10.1007/s00394-0120354-0

234. Thuesen B, Husemoen L, Fenger M, et al. Determinants of vitamin D status in a general population of Danish adults. Bone. 2012;50:605-610. doi:10.1016/j.bone.2011.12.016

235. Scragg R, Holdaway I, Jackson R, Lim T. Plasma 25-hydroxyvitamin D3 and its relation to physical activity and other heart disease risk factors in the general population. Ann Epidemiol. 1992;2:697-703. doi:10.1016/1047-2797(92)90014-H

236. Jungert A, Neuhauser-Berthold M. Dietary vitamin D intake is not associated with 25-hydroxyvitamin D3 or parathyroid hormone in elderly subjects, whereas the calcium-to-phosphate ratio affects parathyroid hormone. Nutr Res. 2013;33:661-667. doi:10.1016/j.nutres.2013.05.011

237. Banihosseini SZ, Baheiraei A, Shirzad N, Heshmat R, Mohsenifar A. The effect of cigarette smoke exposure on vitamin D level and biochemical parameters of mothers and neonates. J Diabetes Metab Disord. 2013;12(1):1-7. doi:10.1186/ 2251-6581-12-19
238. Jorde R, Sneve M, Emaus N, Figenschau Y, Grimnes G. Crosssectional and longitudinal relation between serum 25-hydroxyvitamin D and body mass index: the Tromsø study. Eur J Nutr. 2010;49(7):401-407. doi:10.1007/s00394-010-0098-7

239. Liu N, Sun J, Wang X, Zhang T, Zhao M, Li H. Low vitamin D status is associated with coronavirus disease 2019 outcomes: a systematic review and meta-analysis. Int J Infect Dis. 2021;5864. doi:10.1016/j.ijid.2020.12.077

240. Kazemi A, Mohammadi V, Keshtkar S, et al. Association of vitamin D status with SARS-CoV-2 infection or COVID-19 severity: a systematic review and meta-analysis. Adv Nutr. 2021. doi:10.1093/advances/nmab012

241. Teshome A, Adane A, Girma B, Mekonnen ZA. The impact of vitamin D level on COVID-19 infection: systematic review and meta-analysis. Front Public Health. 2021;9:624559. doi:10.3389/ fpubh.2021.624559

242. Pereira M, Dantas Damascena A, Galvão Azevedo LM, de Almeida Oliveira T, da Mota Santana J. Vitamin D deficiency aggravates COVID-19: systematic review and meta-analysis. Crit Rev Food Sci Nutr. 2020;3:1-9.

243. Ghasemian R, Shamshirian A, Heydari K, et al. The role of vitamin $\mathrm{D}$ in the age of COVID-19: a systematic review and meta-analysis. MedRxiv. 2020:1-20. doi:10.1101/ 2020.06.05.20123554.

244. Nikniaz L, Akbarzadeh MA, Hosseinifard H, Hosseini MS. The impact of vitamin D supplementation on mortality rate and clinical outcomes of COVID-19 patients: a systematic review and meta-analysis. medRxiv. 2021.

245. Yisak H, Ewunetei A, Kefale B, et al. Effects of vitamin D on COVID19 infection and prognosis: a systematic review. Risk Manag Healthc Policy. 2021;14:31-38. doi:10.2147/RMHP.S291584

246. Pinzon RT, Pradana AW. Vitamin D deficiency among patients with COVID-19: case series and recent literature review. Trop Med Health. 2020;48:102. doi:10.1186/s41182-020-00277-w

247. Garg S, Kim L, Whitaker M, et al. Hospitalization rates and characteristics of patients hospitalized with laboratory-confirmed coronavirus disease 2019 - COVID-NET, 14 states, March 1 30, 2020. MMWR. 2020;69(15):458-464.

248. Wakeman MP. A review of the role micronutrient status in the elderly plays in their immune response to viral respiratory infections and the potential compromising effects medications might cause. J Adv Med Med Res. 2020;13:59-85. doi:10.9734/jammr/ 2020/v32i830468

249. Roberts C, Steer T, Maplethorpe N, et al. National diet and nutrition survey results from years 7 and 8 (combined) of the rolling programme (2014/2015 to $2015 / 2016)$. PHE publications. Available from: https://www.gov.uk/government/statistics/ndnsre sults-from-years-7-and-8-combined. Accessed July 16, 2020.

250. Public Health England. Press release: PHE publishes new advice on vitamin D. 2016. Available from: https://www.gov.uk/govern ment/news/phe-publishes-new-advice-on-vitamin-d. Accessed July 16, 2021.

251. Scientific Advisory Committee on Nutrition. Vitamin D and health. 2016. Available from: https:/www.gov.uk/government/ publications/sacn-vitamin-d-and-health-report. Accessed July 16, 2021.

252. Hin H, Tomson J, Newman C, et al. Optimum dose of vitamin D for disease prevention in older people: BEST-D trial of vitamin D in primary care. Osteoporos Int. 2017;28(3):841-851. doi:10.1007/s00198-016-3833-y

253. Griffin G, Hewison M, Hopkin J, et al. Preventing vitamin D deficiency during the COVID-19 pandemic: UK definitions of vitamin D sufficiency and recommended supplement dose are set too low. Clin Med. 2021;21(1):e48. doi:10.7861/ clinmed.2020-0858 
254. Carlberg C, Haq A. The concept of the personal vitamin D response index. J Steroid Biochem Mol Biol. 2018;175:12-17. doi:10.1016/j.jsbmb.2016.12.011

255. Gao L, Maidment I, Matthews FE, Robinson L, Brayne C. Medical Research Council Cognitive Function and Ageing Study. Medication usage change in older people $(65+)$ in England over 20 years: findings from CFAS I and CFAS II. Age Ageing. 2018;47(2):220-225. doi:10.1093/ageing/afx158

256. Charlesworth CJ, Smit E, Lee DSH, et al. Polypharmacy among adults aged 65 years and older in the United States: 1988-2010. J Gerontol A Biol Sci Med Sci. 2015;70:989-995. doi:10.1093/gerona/glv013

257. Guthrie B, Makubate B, Hernandez-santiago V, et al. The rising tide of polypharmacy and drug-drug interactions: population database analysis 1995-2010. BMC Med. 2015;13:74. doi:10.1186/ s12916-015-0322-7
258. Qato DM, Alexander GC, Conti RM, Johnson M, Schumm P, Lindau ST. Use of prescription and over-the-counter medications and dietary supplements among older adults in the United States. $J$ Am Med Assoc. 2008;300:2867-2878.

259. Franchi C, Tettamanti M, Pasina L, et al. Changes in drug prescribing to Italian community-dwelling elderly people: the EPIFARM-Elderly Project 2000-2010. Eur J Clin Pharmacol. 2014;70:437-443. doi:10.1007/s00228-013-1621-6
Risk Management and Healthcare Policy

\section{Publish your work in this journal}

Risk Management and Healthcare Policy is an international, peerreviewed, open access journal focusing on all aspects of public health, policy, and preventative measures to promote good health and improve morbidity and mortality in the population. The journal welcomes submitted papers covering original research, basic science, clinical \& epidemiological studies, reviews and evaluations,

\section{Dovepress}

guidelines, expert opinion and commentary, case reports and extended reports. The manuscript management system is completely online and includes a very quick and fair peer-review system, which is all easy to use. Visit http://www.dovepress.com/testimonials.php to read real quotes from published authors.

Submit your manuscript here: https://www.dovepress.com/risk-management-and-healthcare-policy-journal 